\title{
Política de vivienda para un espacio destruido *
}

\author{
ALICIA ZICGARDI
}

\section{INTRODUCGIÓN}

Las condiciones habitacionales deficientes que prevalecen en México para la mayoría de los trabajadores que habitan el campo y la ciudad constituye un problema social de gran importancia. En la actualidad se calcula que el país presenta un déficit de 5 millones de unidades habitacionales, considerando tanto las nuevas necesidades que genera anualmente el crecimiento poblacional, como la reposición de viviendas deterioradas (Fraga, 1985). En el Distrito Federal, donde este déficit habitacional se estimaba en 800000 viviendas antes del terremoto (DDF, 1984), los trabajadores urbanos han encontrado una alternativa precaria en la creación de colonias populares periféricas, lo cual expandió la ciudad sobre los municipios del estado de México. Este fenómeno de periferización de las clases populares constituye un rasgo central del patrón de urbanización que la gran metrópoli comparte con la mayoría de las ciudades latinoamericanas en las últimas décadas. El centro de la ciudad, en cambio, había sido un espacio con disponibilidad de viviendas para los sectores de bajos ingresos desde la colonia y hasta los inicios del proceso de industrialización que se concentró en la capital del país.

La política habitacional del Estado mexicano frente a la magnitud de estas necesidades ha ido modificándose en el tiempo. El reconocimiento constitucional que se introdujo con la revolución mexicana, según el cual los patrones debían ofrecer vivienda a sus trabajadores, fue reemplazado a principios de los años setenta por la obligación empresarial de aportar a los fondos habitacionales creados entonces (Infonavit y Fovissste). Así,

* Muchas personas contribuyeron a la realización de este trabajo que culminó en febrero de 1986, principalmente los actores centrales de este proceso: los damnificados, las instituciones gubernamentales y los grupos de técnicos y profesionales. También contamos con el apoyo de los alumnos de la Escuela de Trabajo Social de la unam: Guillermo Alvarez, Hortensia Blemont, Irma Lara, María Félix Martínez, María Teresa Reyes y María Teresa Peralta. Lourdes Martínez mecanografió el mismo y Alicia Saloma tuvo a su cuidado los cuadros presentados. Agradecemos toda esta colaboración. 
el Estado comenzó a gestionar una oferta habitacional para los sectores asalariados de mejores y más estables ingresos la cual es muy limitada en relación a la demanda existente.

Para los trabajadores no asalariados de muy bajos ingresos (menos de dos veces y medio el salario mínimo) que representan más del 70\% de la población (Ortiz, 1985) la política gubernamental fue aún más restringida. Desde la congelación de rentas a principios de los cuarenta, el Estado prácticamente no volvió a tener ingerencia en el mercado de vivienda de alquiler. Creó instituciones como fue INDECo y actualmente PONHAPO, que deben atender a ese universo de menores recursos a nivel federal, que disponen de escasos fondos, lo cual restringe su actuación. Ciertamente, el partido gobernante - a través de sus organizaciones- desempeñó un papel estratégico al apoyar los procesos por los que las clases populares accedieron a un terreno en condiciones legales irregulares, autoconstruyeron una vivienda y consiguieron deficientes servicios y equipamiento urbanos.

En medio de esta situación, los terremotos que asolaron a la ciudad de México los días 19 y 20 de septiembre de 1985 pusieron de manifiesto el deterioro habitacional del centro de la ciudad y las limitaciones que presenta la política de vivienda actual. Dejando de lado los edificios que albergaban oficinas del sector público, así como también los establecimientos escolares y hospitalarios, para centrarnos sólo en el problema de la vivienda, 1985 deberá señalar un momento de cambios en la evaluacíón y en la forma de atención de las necesidades de vivienda de interés social porque en adelante deberán considerarse: 1) los habitantes de las deterioradas e insalubres vecindades del centro de la ciudad de México, 2) los habitantes de los conjuntos habitacionales administrados por el sector público (Nonoalco-Tlatelolco y Multifamiliar Juárez principalmente) y 3) los sectores medios que habitaban condominios en renta o en propiedad adquiridos en el mercado privado y que perdieron sus viviendas.

La situación actual generó nuevas prioridades, modificó las formas de actuación que tradicionalmente habían presentado las instituciones que están relacionadas con la vivienda y desarrollo urbano y abre paso a nuevas experiencias de participación social en los procesos de gestión de la vivienda popular.

Por ello, el objetivo de este trabajo es contribuir a la sistematización de las nuevas experiencias que se están desarrollando, aportando elementos que puedan ser recuperados en el proceso de reconstrucción que está en marcha. Para ello presentamos las características del problema habitacional y su entorno en las delegaciones céntricas, luego caracterizamos a la población damnificada y finalmente consideramos los componentes más importantes de la política habitacional que se está desarrollando. El propósito no puede ser otro que el de contribuir a conocer y esclarecer el rumbo del proceso de reconstrucción habitacional de manera que el 
mismo se oriente a ofrecer respuestas adecuadas a las necesidades sociales que surgieron con el desastre.

\section{El TERREMOTO: LOCALIZACIÓN Y EFEGTOS SOBRE LA GIUDAD DE MÉxico}

El 19 de septiembre a las 7 horas y 19 minutos de la mañana, la ciudad de México sufrió la mayor catástrofe de su historia. Un sismo de 8.1 grados de intensidad en la escala de Richter, provocó la muerte de varios miles de personas y destruyó un importante número de edificios. ${ }^{1}$ Las causas de los sismos registrados se atribuyen a la aparición o reactivación de una falla geológica local que ocasionó que los daños y derrumbes en edificaciones estuviesen concentrados en una zona definida de la ciudad. Los informes oficiales señalaron, a reserva de que se realicen estudios con mayor profundidad, que la causa del terremoto "fue el movimiento de la plataforma de Cocos sobre la plataforma continental norteamericana, lo cual generó un desplazamiento que afectó aproximadamente $2530 \mathrm{~km}$ ". Es decir, el foco del sismo estaba a unos $20 \mathrm{~km}$ de la costa del Océano Pacífico, frente a Lázaro Cárdenas en el estado de Michoacán, pero la intensidad del mismo llevó a que las ondas alcanzaran el valle de México prolongándose el temblor durante dos minutos.

La concentración de daños en una parte del territorio de la gran ciudad indica que existe un conjunto de causas que influyeron para provocar los graves daños registrados. La calidad del suelo en la zona céntrica, lugar de asentamiento prehispánico sobre el lago de Texcoco y sobre el cual el conquistador español edificó su ciudad como símbolo de su dominación, impone condicionamientos para la construcción en altura. La ciudad de México fue erigida sobre México-Tenochtitlán con la destrucción del equilibrio ecológico logrado por las civilizaciones indígenas que la habitaron. Las grandes obras de infraestructura que demandó este territorio para tornarlo habitable se iniciaron desde el momento mismo en que se decidió su reconstrucción y perduran hasta nuestros días. La dominación política que demostraba el poderío del conquistador sobre los nativos decidió localizar nuevamente la ciudad a $2240 \mathrm{~m}$ sobre el nivel del mar, en un suelo lacustre, prácticamente cubierto en sus orígenes por un lago, destruyendo un sistema hidráulico perfecto creado por los mexicas. Así, la ciudad de los españoles se reconstruyó en una zona de alto riesgo sís-

1 Un día después, el 20 de septiembre, se registró una réplica de 7.5 grados. Sobre las características de los sismos de septiembre véase entre otros Tinda (1985); Tamez (1985); Rosenblueth (1986). Este último en una entrevista reciente realiza una historia de los principales sismos y sus causas, y sostiene que el macrosismo de 1985 "rebasó lo previsto por todos los reglamentos jamás expedidos por el DF".

2 Según la Comisión Metropolitana de Emergencia. Informe del 19 de septiem. bre al 19 de octubre de 1985. 
mico, amenazada por inundaciones periódicas y que exige la construcción de importantes obras de infraestrucura que acompañen las modificaciones del uso del suelo y garanticen su habitabilidad. Lograr la realización de determinadas obras públicas - como el metro y el drenaje profundo que prácticamente no sufrieron daños- otorgó a la industria mexicana de la construcción prestigio internacional (Fidel y Ziccardi, 1986). Pero a los condicionantes físicos deben agregarse las características de los procesos económicos y sociales que presentaron la construcción y el uso de la ciudad actual: el desafío y la aceptación de diseños arquitectónicos en altura, el no cumplimiento de reglamentaciones legales y especificaciones existentes en materia de construcción, el cambio de uso en algunos edificios, la especulación inmobiliaria que dicta las formas de ocupación, la ausencia de inversiones en mantenimiento para las viviendas populares y los conflictos surgidos entre instituciones y usuarios en los conjuntos habitacionales del sector público, indican también una confluencia de factores presentes en el desastre. La concentración de actividades propias de la economía urbano-industrial así como la localización de los servicios públicos, financieros, comerciales, bancarios provocó que en 1980 habitasen este conglomerado 14274746 habitantes. Solamente las 16 delegaciones políticas del Distrito Federal registraron un total de 9165126 personas. La escasez de vivienda, las dificultades del servicio colectivo de transporte urbano, la precariedad en el acceso a los servicios habitacionales básicos (agua, drenaje) y el elevado grado de contaminación ambiental llevan a que los habitantes de la capital de la República -particularmente la mayoría de los trabajadores de menores recursos- compartan una baja calidad de vida. Pero lo que los sismos evidenciaron es la vulnerabilidad que presenta este espacio urbano en el que un desastre natural encuentra un efecto multiplicador en las propias condiciones de vida que la ciudad of rece a sus habitantes.

Los principales daños ocasionados por el terremoto se concentran en la delegación Cuauhtémoc donde se localiza más de la mitad de los edificios afectados (56\%); sigue en importancia la delegación Venustiano Carranza que concentró el $18 \%$ de las construcciones dañadas. Por esta razón pasaremos a describir algunas características que presentaba la estructura urbana de ambas delegaciones con anterioridad al terremoto, centrándonos en la cuestión habitacional.

\section{Características urbanas de la delegación Cuauhtémoc}

\section{a) Aspectos físicos}

El territorio perteneciente en la actualidad de la delegación Cuauhtémoc se caracteriza por sus suelos lacustres, prácticamente cubiertos en 
sus orígenes por el lago de Texcoco. Las modificaciones que se fueron realizando desde la conquista española para ocupar este sitio alteraron el sistema hidráulico ideado originariamente por los mexicas. Ello provocó inundaciones en varios períodos históricos, no obstante tratarse de una topografía plana con una pendiente no mayor de 5 por ciento (DDF, 1982). La necesaria construcción de infraestructura de obras de agua potable y drenaje reemplazó la ausencia de condiciones naturales apropiadas y garantizó a la población el acceso a estos servicios indispensables. Son precisamente las condiciones naturales de este suelo una de las causas presentes en los daños físicos registrados.

Una intensa circulación de vehículos por sus estrechas calles, comercio mayorista - disminuido en relación a productos perecederos con el traslado en 1982 del mercado de La Merced a la Delegación Iztapalapay una concentración de edificios de la administración pública y de los servicios (bancarios, financieros, personales), se desarrollan en un pequeño espacio en el que el servicio de recolección de la basura que se genera diariamente es ineficiente. A ello se agrega el hecho de que la delegación presenta una marcada escasez de áreas verdes y espacios abiertos, que representan tan sólo el 1.5 por ciento de la superficie total. Existen colonias -particularmente habitadas por sectores medios de la población- que son las que poseen una mejor dotación de espacios abiertos (La Condesa, Hipódromo Condesa, Hipódromo, Roma Sur, Cuauhtémoc y en menor medida la Paulino Navarro y Ampliación Asturias). Sin embargo, en el centro se alcanzan límites alarmantes de contaminación del aire, sumada al ruido que soporta la población que habita y/o trabaja en este territorio, la cual con frecuencia sobrepasa los 80 decibeles (máximo aceptable para proteger la salud de la población).

\section{b) Aspectos históricos}

La delegación Cauhtémoc es el territorio sobre el cual se fundó la ciudad de México. Según la tradición, en el año de 1325 los mexicas fundan México-Tenochtitlán en la orilla poniente del lago de Texcoco. Con ello se cumple el presagio de Huitzilopochtli al ocupar el islote en el que hallaron el águila posada sobre un nopal devorando una serpiente. La ciudad se dividió en cuatro sectores y fue creciendo ganando siempre tierra al lago. Los sitios más destacados fueron el amplio recinto sagrado orientado hacia el poniente en el que se levantaban 78 edificios y la Plaza de Tlatelolco, al norte, donde se hallaba el mercado. El sistema de organización del trabajo comunitario de los indígenas fue aplicado en la construcción de la ciudad central del imperio, siendo admirable el sistema hidráulico en que se sustentó y que permitió el máximo aprovechamiento del territorio y el desarrollo de la agricultura de chinampa. 
En 1519, Tenochtitlán-Tlatelolco albergaba 200000 habitantes en 50000 casas; era más grande que cualquier ciudad europea (Moreno Toscano, 1978 y 1981). En ese año, Hernán Cortés puso sitio a la ciudad y se libraron intensas luchas en las que se destruyeron templos y edificios de manera sistemática. Un par de años después, los españoles comenzaron la reconstrucción en el mismo lugar. En las ruinas de la gran Tenochtitlán se erigió el centro de la capital de la Nueva España. Se delimitó el perímetro central, conocido como traza, donde se localizaron los edificios de gobierno civil y religioso, las principales actividades comerciales y las casas de los españoles. En lo que fuera el recinto sagrado se comenzó a construir la catedral, tarea que demandó trescientos años para su conclusión. Se trazó la plaza mayor, donde se estableció el parián, centro comercial de gran importancia, y se construyó el palacio real. Los indígenas habitaban cuatro barrios periféricos donde construyeron sus casas de acuerdo con sus costumbres y tradiciones. Pero la nueva construcción colonial rompió el equilibrio ecológico que habían sabido lograr los indígenas. Las inundaciones y epidemias de 1629 diezmaron a la población.

Durante toda la época colonial la ciudad fue la capital administrativa y comercial de la Nueva España. La estructura edilicia y de propiedad era demostrativa del poder de la Iglesia. En 1813, de 5520 construcciones, 2016 eran propiedad del clero (Idem). Sus construcciones no sólo se dedicaban al culto religioso sino que el clero controlaba la vivienda en renta existente, la vecindad, que a fines del siglo xvin representaba el 20 por ciento de los inmuebles urbanos.

Las luchas por la independencia de España y la defensa de la ciudad durante la invasión norteamericana de 1847 , concluyeron con la guerra de Reforma. Triunfante Benito Juárez llegó a la ciudad de México en 1861. Durante estos años, creció lentamente; de 170000 habitantes en 1833 pasó a 200000 en 1859, ocupando una extensión de aproximadamente $20 \mathrm{~km}^{2}$. Según María Dolores Morales (1978) tres son las etapas de crecimiento que pueden distinguirse a partir de mediados del siglo pasado hasta el inicio de la revolución: 1) 1858-1883; 2) 1884-1899 y 3) 1900 1910. Interesa recuperar esta periodización puesto que son los años en que se conforman las principales colonias de la delegación Cuauhtémoc. En el primer período, las leyes de Reforma pusieron fin al monopolio que sobre la propiedad urbana ejercía el clero. La expropiación permitió tirar capillas, abrir calles y convertir recintos religiosos en bibliotecas y edificios de la administración pública. El centro cambió su fisonomía, pero la desamortización de los bienes del clero volvió a concentrar la propiedad en manos de una clase compuesta por un número reducido de familias (Cfr. Saldivar, 1985; Berra, 1980). El 43\% de las propiedades rematadas en 1862 fue comprado por 78 personas. A fines del siglo xrx, sólo 7 familias poseían cada una entre 40 y 100 casas. Tres de esas familias (Escandón, Bringas y Limantour) habían iniciado su fortuna como com- 
pradores de bienes nacionalizados. En contrapartida, las viviendas de los trabajadores ofrecían pésimas condiciones de habitabilidad. En esa época comenzaron a realizarse fraccionamientos para expandir el área urbana. Rafael Martínez de la Torre, abogado defensor de Maximiliano y apoderado de Manuel Escandón y del Conde de Regla, fraccionó en 1874 la colonia Obrera de Buenavista (luego llamada Guerrero) y en 1875 fraccionó un millón de metros cuadrados próximos a la avenida Chapultepec (Cfr. Moreno Toscano, 1981 ; Suárez, 1977-1978; Hernández, 19771978). Este período corresponde a la expansión del centro de la ciudad hacia el norte en que mejoran las condiciones habitacionales de los barrios de Santa Ana, Tlatelolco y Peralvillo, creándose las colonias Barroso, Santa María y Guerrero (llamada originariamente Buenavista o San Fernando), Arquitectos y Violante (en el barrio de Tepito).

En el segundo período se crean colonias para los sectores de menores recursos hacia el noreste, propiciadas por la construcción de la penitenciaría, el rastro, la estación Hidalgo y las vías de los ferrocarriles Guadalupe, Interoceánico y de Cintura; ello da origen a las colonias: Morelos, La Bolsa, Díaz de León, Maza, Rastro y Valle Gómez, al poniente; Santa Julia y San Rafael (esta última de clase media) y hacia el sur la Limantour o Candelaria Atlampa, Indianilla e Hidalgo.

En la última etapa (1900-1910) surge el sur poniente como espacio destinado a las clases altas de la población, dotado de los servicios y equipamientos adecuados: de la Teja (que toma los nombres de Paseo, Americana, Nueva del Paseo, Juárez y Cuauhtémoc localizada a ambos lados del Paseo de la Reforma), la Roma y la colonia Condesa.

En esta última etapa del porfiriato, la delegación Cuauhtémoc presentó importantes modificaciones arquitectónicas. El desarrollo económico capitalista transformó en 20 años la ciudad: nuevos fraccionamientos, nuevas construcciones, nuevos materiales y diseños afrancesados cambian el aspecto de esta área central. Los contrastes se hicieron más evidentes; la ciudad era embellecida a través de la construcción de majestuosos edificios que dieron en llamarse "palacios". El comercio concentrado en el centro de la ciudad dio origen a la formación del área de La Merced, donde se localizó hasta 1982 el principal centro de abasto de productos perecederos del país. ${ }^{8}$ En esta área se desarrollaron intensas actividades de comercialización de todo tipo de productos. De igual forma, los mercados de Tepito, de venta de objetos de diferentes tipos y de la Lagunilla, comenzaron a funcionar en el siglo pasado. En contrapartida, los pobres de la ciudad soportaban condiciones infrahumanas; en el casco antiguo, el tifo seguía siendo una enfermedad endémica y 100000 personas seguían hacinadas en insalubres vecindades. A fines del régimen porfirista, la ciudad tenía $33 \mathrm{~km}^{2}$ y se habían realizado también importantes obras de desagüe, introducido el alumbrado y el adoquinado de las principales

3 Sobre la Merced consultar Héctor Castillo Berthier (1983). 
calles y construido monumentos (a Colón, Cuauhtémoc y Juárez, y la Columna de la Independencia). Los nuevos medios de transporte, el tranvía eléctrico y el trolebús dieron entrada a colonias más alejadas del centro, entre ellas Valle Gómez y Escandón.

Con la revolución mucha gente huyó a las afueras de la ciudad, las mujeres recorrían los mercados de San Juan, La Merced y La Lagunilla en los que escaseaban los alimentos, mientras el desempleo y la miseria se incrementaban. Estabilizado el régimen, nuevos fraccionamientos son abiertos por los caudillos de la revolución. Erika Berra (1980) indica que de 1921 a 1926 se formaron 19 colonias, entre éstas la Ex-Hipódromo de Peralvillo y San Simón Tolnáhuac que se consolidaron en los años treinta con la introducción de servicios y equipamientos. ${ }^{4}$ En los años cincuenta la ciudad tiende a crecer hacia el oriente y el norte, actualmente las delegaciones Venustiano Carranza y Azcapotzalco. La colonia Roma ya toma su traza definitiva y se satura; se construye para los sectores medios el multifamiliar Benito Juárez y se concentran los servicios hospitalarios al localizarse allí el Centro Médico Nacional. A principios de los años sesenta se construye el que entonces era el mayor complejo habitacional y urbano: la Unidad Nonoalco-Tlatelolco. Precisamente es esta década en la que se acelera la expansión de la ciudad sobre la periferia; el centro, en cambio, mantendrá su población e incluso años después comenzará a perderla.

\section{c) Aspectos poblacionales}

Actualmente, la delegación Cuauhtémoc se extiende sobre una superficie de 3309.3 hectáreas que representan el $2.97 \%$ de la superficie territorial urbana de la zona metropolitana de la ciudad de México. En 1980 registrada 843283 habitantes y presentaba — respecto a la década anterior - una tasa de crecimiento poblacional negativa $(-1.39) .^{5}$

La fuerza de trabajo que habita en este territorio se desempeña principalmente ( $55.7 \%$ de la PEA) en actividades relacionadas con el intenso comercio generado por la concentración de mercados y servicios.

El 39.5\% de los trabajadores se halla inserto en actividades manufactureras; particularmente, la industria textil y la del cuero absorben una importante proporción de fuerza de trabajo femenina. Ese total representa el $10.73 \%$ de la población económicamente activa del DF y el $7.30 \%$ del total de la zMGM.

4 Sobre la formación de las colonias populares en la década de los años treinta véase Manuel Perló (1981); Alicia Ziccardi (1982).

5 Los datos socioeconómicos y demográficos y de vivienda han sido extraídos de Gustavo Garza (coordinador) (1986), y han sido elaborados con base en los Censos Nacionales de Población y Vivienda. En 1970 la Delegación Cuauhtémoc registraba 969406 habitantes, en 1960, 1024389 y en 19501049079 habitantes. 
El centro permite la sobreviviencia de un importante número de personas que no encuentran trabajo estable y bien remunerado. La venta de todo tipo de productos en las concurridas calles del primer cuadro garantiza la existencia de una fuente de ingresos. Por ello, lo fundamental para la población que habita en las colonias populares es la permanencia en este espacio en el que se localiza este mercado de trabajo, al cual accede cotidianamente sin realizar prácticamente gastos de transporte.

Para las capas medias, la delegación ofrece condiciones adecuadas de empleo. Las actividades de gobierno así como la concentración de oficinas privadas $\mathrm{y}$ servicios bancarios $\mathrm{y}$ financieros ofrecen un importante número de opciones ocupacionales a este sector social. El acceso a los principales servicios públicos, así como a los equipamientos culturales y recreativos, constituye uno de los principales atractivos para los habitantos de colonias tales como la Roma, Condesa, Juárez y Cuauhtémoc.

\section{d) La vivienda y su entorno}

En 1980, la delegación Cuauhtémoc presentaba 198530 viviendas, con un promedio de 4.07 por ciento de ocupantes en cada una. Sus condiciones materiales, medidas en función del acceso a los principales servicios, son comparativamente buenas. El 93 por ciento del total de las viviendas presenta drenaje o fosa séptica y el 85 por ciento agua entubada dentro de la casa. De igual forma, el 93 por ciento de esas viviendas fueron edificadas con muros de tabique o similares y poco más de la mitad (54 por ciento) tenía 3 o más cuartos. ${ }^{6}$ Estos datos globales no son suficientes para aproximarnos a las condiciones de vida que presentan las diferentes colonias que forman parte de la delegación. Ampliando lo señalado en el punto anterior, las colonias habitadas por las clases medias como la Roma Norte y Sur, la Condesa, la Hipódromo-Condesa, la Hipódromo, la Cuauhtémoc y la Juárez son las que presentan mejores condiciones habitacionales; tienen garantizado el acceso a los principales servicios y equipamientos y son las mejor dotadas de espacios verdes. El acceso y uso de estas viviendas, cuya tenencia es en propiedad o en renta, se rigen por las características del mercado y de acuerdo con las reglamentaciones legales vigentes. Para los sectores de menores recursos, la principal opción habitacional ha sido las vecindades en las cuales las familias de trabajadores, de un promedio de cinco o más miembros, viven mayoritariamente en un cuarto. Estas vecindades proliferan en las colonias Guerrero, Morelos, Doctores, Santa Ma. la Ribera, Buenavista, la Obrera, Paulino Navarro, Tránsito, Esperanza, Peralvillo, Valle Gómez y Ex-Hipódromo. de Peralvillo. El deterioro en que se encontraban por falta de manteni-. 
miento ha provocado que los sismos de septiembre pasado produjeran graves daños en estas viviendas y quedaran sin casa miles de familias. Las dificultades existentes entre los propietarios e inquilinos llevaron a que el gobierno federal decretara la expropiación de alrededor de 4000 predios en los cuales se localizaban esas viviendas populares.

La acción de los organismos públicos de vivienda sobre el territorio de la delegación Cuauhtémoc ha representado la construcción de 30 conjuntos de 18232 viviendas edificadas hace más de una década. ${ }^{7}$ El Multifamiliar Juárez y la Unidad Tlatelolco son de las primeras viviendas en condominio vertical que fueron construidas ante el déficit habitacional que presentaba ya la ciudad de México para los sectores asalariados de mejores ingresos y financiadas por instituciones gubernamentales. Ambos conjuntos sufrieron trágicos efectos del terremoto. En el Multifamiliar Juárez debieron ser demolidos varios edificios. En Tlatelolco, el edificio Nuevo León se derrumbó en el momento en que se produjo el movimiento telúrico y habrá que demoler 20 edificios del monumental conjunto formado por 106 edificios que albergaban a más de 50000 personas. $^{8}$

La delegación Cuauhtémoc goza de un buen nivel de dotación de servicios habitacionales básicos. El suministro de agua potable, drenaje y alcantarillado, energía eléctrica y alumbrado público se hallan garantizados para el territorio que ocupa la delegación. Sin embargo, en las colonias donde habitan los sectores de menores ingresos existe escasez de agua y los servicios de drenaje son deficientes. Entre las consecuencias del sismo deben mencionarse los daños que presentaron las redes de agua y que hicieron que durante varias semanas faltase en muchas viviendas.

Las posibilidades de mejorar las condiciones de vida de los sectores más pobres de la población radican en que exista una infraestructura que garantice el acceso a los principales servicios, situación ésta marcadamente diferente a la que enfrentan quienes habitan las precarias colonias populares de la periferia. De igual forma, la delegación Cuauhtémoc ofrece un nivel de equipamiento adecuado a la demanda de la población que en ella habita, en materia educacional, hospitalaria, comercial y cultural. Los principales servicios urbanos (correos, teléfonos, oficinas, bancos) ofrecen atención no sólo a sus habitantes sino a los de otras delegaciones (Cfr. DDF, 1982).

La vialidad que presenta la delegación Cuauhtémoc es suficiente y en buen estado. El perímetro de la delegación lo constituyen vías rápidas y de acceso controlado. Los mayores problemas de circulación y congestionamiento se presentan en el centro de la ciudad, habiendo sido éste uno de los principales motivos por los cuales se decidió el traslado de La Mer-

7 Idem.

8 Informe SEDUE, 1986 ante la Comisión Especial Pluripartidista del Congreso de la Unión. Excélsior del 14 de febrero de 1986 informaba que 17 edificios son los que deberán desalojarse. 
ced a la delegación de Iztapalapa. Por las estrechas calles del centro circula un considerable número de vehículos que atraviesa la ciudad y cuyo destino final es otro diferente a la delegación. La situación es aún más crítica porque las calles tienden a saturarse de carros estacionados ante la falta de un servicio de estacionamiento accesible -en localización y precio- a los usuarios. La conservación de las vialidades es buena aun cuando en las colonias más pobres se advierte que el pavimento está deteriorado; en muchos casos como consecuencia del peso exagerado que soporta por el tránsito de los vehículos de carga que tienen alli sus terminales.

La demanda de transporte público está satisfecha en la totalidad del territorio de la delegación. A la importante cantidad de líneas de autobuses, taxis y peseros, se agrega la disponibilidad del metro. Este servicio colectivo, a través de cuatro de sus siete líneas (1, 4, 5 y 8 ), ofrece servicio directo a importantes colonias como Tlatelolco, Guerrero, Morelos, Centro, Juárez y Cuauhtémoc.

En el Centro Histórico de la ciudad de México se hallan instaladas diversas dependencias de los poderes de la Unión: el Ejecutivo, el Judicial y Legislativo. De este último, la Cámara de Diputados fue trasladada a un nuevo edificio en las proximidades de la estación San Lázaro. Con anterioridad al terremoto se ubicaban en este territorio 13 dependencias del ejecutivo, 79 oficinas paraestatales y entidades no sectorizadas, 17 instalaciones de la administración pública central, 2 instalaciones de la administración pública descentralizada, 6 agencias del ministerio público, 2 reclusorios administrativos, 3 batallones de policía y el batallón de granaderos y frente a la Plaza de la Constitución se encuentran localizadas las oficinas centrales del Departamento del Distrito Federal. Esta concentración territorial de actividades de la administración pública, en un alto porcentaje localizada en edificios rentados a propietarios privados, llevó a que los efectos del terremoto sobre las mismas fuesen de gravedad. Hubo edificios del conjunto Pino Suárez, que albergaba tribunales civiles, que sufrieron daños irreparables.

En cuanto a los servicios, en la delegación se localiza el Palacio de Correos, el cual ofrece servicios al conjunto de la población capitalina. La avenida Paseo de la Reforma, así como la Zona Rosa y el centro de la ciudad, ofrecen la principal oferta de servicios turísticos dentro de la misma. Este sector fue seriamente afectado por el desastre de septiembre, puesto que dejó en ruinas importantes edificios, como el Hotel Regis, construido a principios de siglo, donde murió un número considenable de personas. Existen otros hoteles de la Alameda Central que sufrieron graves daños.

La recolección de basura es un servicio deficitario, lo cual genera una situación de deterioro, particularmente en la zona de La Merced y de los mercados cercanos. Esto, sumado a la emisión de gases y polvos y a la. 
carencia de áreas verdes, convierte a esta zona en una parcela del territorio de la ciudad con elevados índices de contaminación.

Finalmente debe mencionarse que en esta delegación el arraigo de una población que durante generaciones ha habitado en estas colonias de las clases populares ha dado origen a la existencia de organizaciones vecinales que han ejercido importantes acciones para mejorar las condiciones de vida que prevalecen. El barrio de Tepito ha sabido desarrollar formas organizativas en defensa de sus viviendas populares y de sus fuentes de trabajo (Suárez, 1978; copevi, 1974). Algunas colonias, como la Ex-Hipódromo de Peralvillo o la Paulino Navarro y la Buenos Aires, encierran una historia de paulatino mejoramiento sobre terrenos fraccionados después de la revolución. Justamente estas colonias han sido las primeras experiencias cooperativas de desarrollo urbano formadas por las clases populares de la ciudad de México (Ziccardi, 1982). Los vecinos de Tlatelolco han desarrollado diferentes asociaciones representativas de su interés colectivo. Estas organizaciones que han persistido en el tiempo constituyen formas organizativas de las clases medias y de los sectores populares en defensa de la calidad de vida de los habitantes de estas colonias.

\section{Características urbanas de la delegación Venustiano Garranza}

\section{a) Aspectos físicos}

La delegación Venustiano Carranza se localiza en el lado este del área central del Distrito Federal y ocupa una extensión de 3442.1 hectáreas. Esta superficie representa el $1.07 \%$ del total de la superficie territorial del área metropolitana de la ciudad de México y el 3.09 por ciento de su área urbanizada (Garza, 1986). Su suelo presenta similitud con los de la delegación Cuauhtémoc, siendo predominantemente lacustre.

Las áreas verdes representan sólo el 1.5 por ciento de la superficie de la delegación, lo que impide que estos espacios actúen como zonas de oxigenación y recarga acuífera (DDF, 1982). A ello se suman las tolvaneras provenientes del ex lago de Texcoco que contaminan la atmósfera. $\mathrm{Al}$ mismo tiempo, las propias actividades económicas desarrolladas en su territorio constituyen una constante fuente de contaminación ambiental. El área donde se localizan los importantes centros de comercialización como son la zona de La Merced y de los mercados de Sonora, Jamaica, La Viga, carecen de un servicio de recolección de basura eficiente. El transporte que originan dichas actividades comerciales, así como las terminales y estaciones importantes del metro (Zaragoza, Candelaria, San Lázaro) contribuyen marcadamente a contaminar el medio ambiente mediante la emisión de humos, gases y ruido. El Aeropuerto Internacional de la ciudad de México es otro factor que genera condiciones ambientales desfavora- 
bles para la población que habita en las colonias próximas; en éstas la contaminación acústica excede los niveles de 80 decibeles fijados como límite máximo para proteger la salud de los habitantes. La propia geografía hace que los gases (ozono, óxidos de nitrógeno, hidrocarburos, monóxidos de carbono, etcétera) en lugar de dispersarse queden en el interior del valle (Cfr. Grajales y Lara, 1983).

El principal uso que presentan las 3442.1 hectáreas que ocupa la delegación es el habitacional, el cual representa prácticamente la mitad (49 por ciento del total). El 28 por ciento corresponde a usos mixtos, el 18 por ciento a servicios y el 3.0 por ciento está dedicado a usos industriales. Sin embargo existen terrenos baldíos los cuales pueden saturarse e incrementar así la densidad de la población (DDF, 1982). La densidad de la delegación es muy superior a la del Distrito Federal en su conjunto (70.31 de densidad neta); alcanza 208.37 habitantes por hectárea (Garza, 1986).

El Plan Parcial Delegacional identifica zonas dedicadas a usos especializados y a usos mixtos con predominio habitacional. Entre las primeras se pueden distinguir colonias en las que prevalecen las actividades industriales, tales como las colonias Progresista, Santa Cruz y Aviación; usos comerciales como las que forman parte de la zona de La Merced y los mercados de Sonora y Jamaica; zonas de comercio concentrado sobre vialidades importantes como Boulevard Puente Aéreo, Ignacio Zaragoza, Canal del Norte, Inguarán y Eduardo Molina. Entre las zonas predominantemente habitacionales pueden mencionarse las que conforman las colonias Jardín Balbuena, 24 de abril, Âlvaro Obregón, Moctezuma, 10 de mavo y 7 de julio con usos habitacionales unifamiliares y multifamiliares, buen nivel de habitabilidad e índices medios de densidad; el área que integran las colonias Venustiano Carranza, Michoacán, 20 de noviembre, Progresista, Penitenciaría, Romero Rubio y Pensador Mexicano se caracteriza por su uso habitacional unifamiliar y multifamiliar, deficientes servicios habitacionales y densidad media. Las colonias Puebla, Ignacio Zaragoza, Gómez Farías, Federal, Cuatro Árboles y Aviación Civil son de uso habitacional unifamiliar y plurifamiliar y presentan condiciones habitacionales deterioradas y densidades bajas. Finalmente, el área comprendida por las colonias El Arenal, A. López Mateos y Caracol, son viviendas unifamiliares con niveles de construcción regulares y densidades medias. Esto indica que aun con una forma de ocupación muy heterogénea en cuanto a condiciones de habitabilidad, esta delegación es un espacio ocupado predominantemente por viviendas populares y presenta un alto grado de irregularidad en la tenencia de la tierra: de 66 colonias, 53 presentan situaciones de propiedad jurídicamente confusas.

\section{b) Aspectos históricos}

La delegación Venustiano Carranza forma parte del más antiguo territorio ocupado por la ciudad de México. Desde mediados del siglo pa- 
sado y particularmente después del proceso de Reforma que expropió los bienes del clero comenzó la expansión de la zona central de la ciudad. Un conjunto de nuevos fraccionamientos venía a satisfacer la demanda de vivienda que presentaban los sectores populares urbanos. La construcción del Palacio de Lecumberri, edificio panóptico que pretendió albergar una prisión modelo del porfiriato, dio origen a la expansión de las colonias próximas (Penitenciaría, Venustiano Carranza, Azteca).

La introducción de medios de transporte colectivo permitió que se llevara a cabo dicha expansión y construcción:

"Por el nororiente de la ciudad, la estación de San Lázaro y el F.C. de Cintura se encontraban cerca de las colonias Morelos (1886); La Balsa (1892) y Sheibe (1904). El circuito 'Penitenciaría-Peñón' (1889) facilitó la formación de la colonia Sheibe; también la colonia Romero Rubio se vio afectada y su formación data del año de $1907 .$. La estación del F.C. Hidalgo estaba entre las colonias La Maza (1894), Valle Gómez (1899) y Rastro (1889)", (Vidrio, Manuel, 1978)..$^{9}$

La intensa actividad comercial existió desde siempre por La Merced y la construcción de su mercado en 1957 (Castillo B., Héctor, 1983); otros mercados próximos como el mercado de Sonora y Jamaica llegaron a que se generase en este espacio el mayor volumen de transacciones comerciales del país. Esto generó un conjunto de actividades económicas y consecuentemente se transformó en una importante fuente de empleos en el centro de la ciudad.

En 1928 inició sus actividades el primer aeropuerto del país -el Aeropuerto Internacional Benito Juárez- en lo que entonces eran las afueras de la ciudad. Alrededor de éste se fueron formando grandes fraccionamientos (Progresista, Moctezuma, Jardín Balbuena) quedando el aeropuerto localizado finalmente en un área urbana (Grajales, Carolina, 1983). Al mismo tiempo la ocupación masiva de tierras en Nezahualcóyotl, municipio colindante del estado de México, particularmente en los sesenta, llevó a que el territorio de la delegación incrementara su área ocupada y se transformara en un espacio de intenso tránsito de mercancías y personas que se dirigen cotidianamente a los estados de México y Puebla.

\section{c) Aspectos poblacionales}

En 1980, la delegación estaba habitada por 717221 personas y presentaba una tasa de crecimiento poblacional negativo de -0.87 , en la década de los setenta. ${ }^{10} \mathrm{La}$ población en disponibilidad de trabajar ascien-

9 Los años entre paréntesis pertenecen a los años de creación de la colonia, según lo especifica Manuel Vidrio (1978).

10 En 1970 habitaban la Delegación Venustiano Carranza 782762 personas, en 1960, 604100 personas y en 1950, 398045 personas. Cfr. Garza (1986). 
de a 261736 personas, que representan el 7.9\% de la Población Económicamente Activa y el $5.4 \%$ de la Zona Metropolitana de la Ciudad de México. ${ }^{11}$ Estos trabajadores urbanos desempeñan predominantemente actividades económicas del sector terciario $(60.6 \%)$. Los servicios de la producción (comercio principalmente y servicios personales) absorben un elevado porcentaje de la fuerza de trabajo que habita este territorio. De igual forma, la pequeña industria y los talleres artesanales ofrecen empleo a una tercera parte de la población económicamente activa $(33.1 \%)$. Sin embargo, la inestabilidad y los bajos salarios implican una precaria calidad de vida para la mayoría de las familias.

\section{d) La vivienda y su entorno}

En 1980 existían en la delegación Venustiano Carranza 142197 viviendas. $\mathrm{El}$ promedio de ocupantes era de alrededor de 5 personas, indicador del grado de hacinamiento en el que vive un alto porcentaje de la población para quien su vivienda se compone de un cuarto en una vecindad en condiciones de deterioro. ${ }^{12}$

El Censo de 1980 indicaba que las viviendas que poseen drenaje representan el 92 por ciento, mientras que la provisión de agua potable se limitaba a cubrir tan sólo el 73 por ciento de las mismas. Casi la totalidad son viviendas de muros de tabique o similares (93 por ciento) pero la falta de mantenimiento adecuado en un importante número llevó a que el terremoto de 1985 destruyera, total o parcialmente un número considerable. El desastre sólo puso en evidencia la situación de deterioro habitacional existente en el centro de la ciudad de México.

Las zonas de los conjuntos habitacionales financiados por el sector público, la Unidad Kennedy en Jardín Balbuena, la Unidad Zaragoza en la colonia Cuatro Árboles y la Candelaria de los Patos en la del mismo nombre, son colonias de alta densidad habitacional. Constituyen la opción habitacional para los trabajadores asalariados que gozan de estabilidad en el empleo. En total, los conjuntos financiados por organismos del sector público localizados en la Delegación Venustiano Carranza son 34 y representan 11978 viviendas.

Prácticamente la totalidad de los habitantes de la delegación Venustiano Carranza tiene garantizado el acceso a los servicios habitacionales básicos: agua potable, drenaje y energía eléctrica. En términos generales, la red de agua potable es muy antigua y la falta de un mantenimiento ocasiona un suministro deficitario. En cuanto al drenaje, la delegación es atravesada de sur a norte por el interceptor oriente y dispone de redes primaria y secundaria que dan servicio a casi la totalidad de las vivien- 
das. Las dificultades respecto a éste son menores, aún cuando la zona norte presenta graves problemas de encharcamiento, situación que puede hacerse extensiva a toda la delegación. Cuenta con mejor red primaria que drenaje. Hay colonias, como las localizadas al oriente (Caracol, Arenal, Adolfo López Mateos, Aviación Civil, Ampliación Peñón y la periferia inmediata al aeropuerto), que tienen insuficiente dotación de agua y problemas de drenaje (particularmente sobre la avenida Ignacio Zaragoza). Esta situación puede atribuirse a la saturación de las redes que originariamente fueron construidas para un número mucho menor de usuarios que los que existen en la actualidad. La zona poniente (que incluye las colonias Morelos, Penitenciaría, Artes Gráficas, Rastro, Venustiano Carranza y Popular) presenta una red con tramos deteriorados por la falta de mantenimiento, lo cual provoca fugas, pérdidas de presión y escasez de agua (DDF, 1982).

En cuanto a la energía eléctrica, no existen problemas en su suministro; inclusive la mayor parte del alumbrado público es de lámparas de vapor de sodio. La delegación cuenta con un buen nivel de equipamientos escolares, aunque la demanda educacional tiende a crecer sostenidamente, provocando un déficit de vacantes en el nivel medio. Las instalaciones culturales son limitadas; sobre todo las bibliotecas. Los centros recreativos son de los más importantes del Distrito Federal, como es el caso de parte de la Ciudad Deportiva.

La intensidad del tránsito de vehículos que tiene como punto final la delegación lleva a que el estacionamiento en la vía pública haya alcanzado un nivel crítico ante la carencia de estacionamientos. Otros problemas de circulación que presenta la delegación deben atribuirse a la existencia de 400 terminales de camiones de carga y transporte, lo cual provoca agudos problemas de congestionamiento, particularmente en Anillo de Circunvalación y Río Consulado (Idem). Este tipo de vehículos de carga pesada afecta notablemente las vialidades de algunas colonias (como ocurre en la Lorenzo Boturini). Por otra parte, la influencia y la demanda de servicios de transporte que genera ciudad Nezahualcóyotl lleva a que la calzada Zaragoza presente periódicamente embotellamientos.

En cuanto al transporte público, éste da servicio en aproximadamente el 70 por ciento del territorio de la delegación. El metro constituye un medio de transporte fundamental para esta delegación. Cuatro líneas atraviesan su territorio, la línea 1 (Observatorio-Pantitlán), la línea 4 (Santa Anita-Martín Carrera), la línea 5 (Pantitlán-Politécnico) y la línea 6 (Martín Carrera-El Rosario). En las terminales del metro se presentan problemas de deterioro ambiental puesto que los intensos movimientos de traslado de autobuses provocan elevados niveles de polución y ruido.

La carencia de servicios urbanos eficientes, como el de recolección de basura, contribuye a agravar los problemas de contaminación y deterioro que presenta la delegación. 
La delegación aloja desde hace unos años el nuevo edificio del Palacio Legislativo, el cual ha generado en sus alrededores una intensa actividad de servicios. De igual forma, el Aeropuerto Internacional de la Ciudad de México concentra en su interior servicios de comunicación (correos, teléfonos) y bancarios, a la vez que ha comenzado a ofrecer servicios turísticos (hoteles) en las proximidades.

Algunas de las colonias que conforman la delegación Venustiano Carranza, las localizadas en el límite con la delegación Cuauhtémoc, han sido producto de procesos de ocupación del suelo protagonizados por los sectores populares desde los años treinta. Los fraccionamientos más antiguos carecían inicialmente de los servicios más elementales y ofrecían tan sólo condiciones de vida precarias. Con el tiempo, las organizaciones comunitarias de vecinos fueron introduciendo mejoras. Las colonias de los sectores populares, tal como las conocemos actualmente, son el producto de largos años de trabajo colectivo y organización social necesaria para que el Estado provea estos servicios.

\section{LOS DAÑos Físicos}

Localizados predominantemente en determinado sector de la ciudad, el mayor número de inmuebles afectados es de uso habitacional (cuadro núm. 1). De 5723 inmuebles reportados por la Comisión Metropolitana de Emergencia, el $65 \%$ corresponde a viviendas, el $15 \%$ es de uso comercial, el $12 \%$ es de establecimientos escolares y el $6 \%$ de oficinas. ${ }^{13}$ En los establecimientos hospitalarios, aunque representan el $1 \%$ de los inmuebles afectados, las pérdidas son cruciales. De 41 hospitales afectados, 22 sufrieron daños mayores, debiendo ser demolida parte del Centro Médico Nacional. Es decir, el principal problema, el más acuciante y el que inmediatamente demandó los mayores esfuerzos, fue el de ofrecer un albergue temporal o definitivo a las miles de familias damnificadas por el terremoto. Según la misma fuente, 859 inmuebles presentan derrumbe parcial o total, es decir, un 15 por ciento del total de edificios afectados. Pero más de 2000 presentaban fracturas o desplome de sus estructuras, lo cual los torna seguramente inhabitables, y otro tanto presentan daños menores (Comisión Metropolitana de Emergencia, informe del 19 de octubre de 1985).

Más de un centenar de edificios presentaron daños de tal magnitud que hubo que ordenar su demolición para lo cual se realizaron evaluaciones inmediatas con base en criterios de riesgo, necesidad y costo. De igual forma el Departamento del DF ordenó la desocupación de 631 edificios por

13 De los predios correspondientes a oficinas 196 son del sector público pero de éstas sólo el $1.5 \%$ son de propiedad gubernamental mientras que la mayoría estaban rentadas a particulares. 
CUADRO 1

INMUEBLES AFECTADOS SEGÚN USO

\begin{tabular}{lrc}
\hline Uso & Num. & $\%$ \\
\hline Habitacional & 3746 & 65 \\
Comercial & 840 & 15 \\
Educacional & 704 & 12 \\
Oficinas * & 345 & 6 \\
Hospitalario ** & 41 & 1 \\
Recreativo & 33 & 1 \\
Industrial & 19 & - \\
Total: & 5728 & 100 \\
\hline
\end{tabular}

* De 196 inmuebles de Oficinas Públicas afectados, sólo el $1.5 \%$ era de propiedad federal; la mayoría eran rentados a particulares.

** 22 sufrieron daños mayores.

FUENTE: Elaboración propia con base en el Informe de la Comisión Metropolitana de Emergencia del 19 de septiembre al 19 de octubre de 1985.

daños directos de inmuebles y 99 por daños de edificios colindantes y de 1063 edificios ubicados en distintas zonas hubo que retirar vidrios, losetas y aplanados porque sus fachadas se vieron fuertemente afectadas. ${ }^{14}$

Otras estimaciones realizadas tienden a incrementar notablemente las cifras del parque inmobiliario afectado. La Dirección General de Reordenación Urbana y Protección Ecológica del DDF declaró que se estaba realizando un programa de información mínima sobre las condiciones de cada inmueble y que el mismo debía cubrirse antes del 4 de diciembre de 1985. No obstante, adelantaron la realización de un conjunto de acciones en número muy superior de inmuebles a los considerados por la Comisión Metropolitana de Emergencia. Según esa Dirección del Departamento del DF era necesario realizar: apuntalamientos por riesgo en aproximadamente 1000 vecindades, reparación por daños menores en 3640 viviendas, rehabilitación y mejoramiento en 2190 viviendas, demolición y reconstrucción en 5482 viviendas. Es decir, presentaba una situación más grave. Uno de los cálculos más alejados de las cifras oficiales

14 Respecto a las necesidades de demoler edificios y los procedimientos para ejecutarlos la prensa fue informada periódicamente. Véase Excélsior, 17 de diciem. bre y 28 de octubre de 1985 y Metrópoli, del 1 de octubre de 1985. Un listado oficial de edificios a demoler fue publicado en Excélsior el 26 de septiembre de 1985. 
fue el realizado por la GEPAL (1985) el cual indica en un informe preliminar que "se perdieron y deberán demolerse alrededor de 30000 viviendas y se dañaron más o menos 60000 más". "Sólo Tlatelolco, continúa el informe, tenía un total de más de 100 edificios con un promedio superior a 100 departamentos; se van a demoler 23 unidades familiares" (CEPAL, 1985:12). La GEPAL estimó que el costo actual de reposición de las edificaciones destruidas alcanzaba los 158500 millones de pesos, mientras que el de reparación de unidades que resultaron dañadas se sitúa en los 21800 millones de pesos. A ello agregaba el valor del mobiliario alrededor de 26400 millones de pesos más, de manera que la pérdida total para el sector vivienda alcanzaría a 180300 millones de pesos, sin incluir el valor de los terrenos para edificación. El mismo informe evaluaba que la pérdida total alcanza alrededor de 1300000 millones de pesos mexicanos ( 1 billón 300) o sea, alrededor de 4000 millones de dólares. Esta cantidad en términos relativos equivale al $2.7 \%$ del PIB estimado para 1985, el $13.5 \%$ de la formación bruta de capital del mismo año o el $11 \%$ del gasto total del gobierno federal. ${ }^{15}$ Es decir, se trata de una suma comparativamente pequeña. Pero lo importante es considerar que el desastre se produjo en una coyuntura en que la economía mexicana no ha conseguido superar la situación de crisis inaugurada en los primeros años de los ochenta y que persisten serios desequilibrios internos y externos. Por ello la reconstrucción debe entenderse no solamente como un gasto de gobierno sino como un problema más a ser afrontado por el elenco gubernamental en una coyuntura de reducción del gasto público. Por otra parte, si hay un sector de la economía que efectivamente va a verse reactivado, es el sector de la industria de la construcción, el cual en el momento del sismo presentaba un porcentaje importante de capacidad ociosa. Para este sector no sólo la reconstrucción, sino las demoliciones y limpieza de la ciudad, constituyen actividades de interés. Por otra parte, su capacidad de creación de empleos masivos en el medio urbano lo torna atractivo a la inversión pública. ${ }^{16} \mathrm{~A}$ ello se agrega ahora el hecho de que lo fundamental

15 La forma como la cepal estimó estas pérdidas fue considerando que se trataba de unidades de $70 \mathrm{~m}^{2}$ y a un costo de 50000 por $\mathrm{m}^{2}$ (cuando se trataba de daños totales). Para daños parciales estimaron que el costo de reparación era equivalente al $10 \%$ del de reposición total. Por demoliciones se calculó una erogación cercana a 46800 millones, al estimarlo como el 5\% del valor de las edificaciones destruidas o por demoler. Cfr. CEPAL (1985) pág. 13. Al mismo tiempo estiman que el monto total de las pérdidas asciende a 1.3 billones de pesos mexicanos o sea 4103 millones de dólares de los cuales el $87 \%$ corresponde a daños directos de infraestructura y el $13 \%$ a indirectos (pérdidas por ingresos o de producción. gastos de emergencia, etcétera).

16 Véase Carlos Fidel y Alicia Ziccardi (1986). Excélsior del 22 de noviembre de 1985 informaba al respecto: "La tarea de construcción y reconstrucción de viviendas generará miles de empleos a partir de la semana próxima, y en la contratación de mano de obra se dará preferencia a damnificados... informó ayer el arquitecto José Parcero López, titular del organismo gubernamental de Vivienda Popular". 
es atender prioritariamente la construcción de viviendas de los sectores de menores recursos, los cuales ven incrementar su penuria de supervivencia frente a la crisis al perder sus precarias viviendas. Pero existen también otros elementos que deben estar presentes en la reconstrucción y que algunas disposiciones dadas a conocer parecen contemplar, tales como la prohibición de construir más que un determinado número de pisos en altura, el crear espacios verdes en los predios donde se derrumbaron edificios, el ejercer mayor control sobre el cumplimiento de las normas y especificaciones vigentes, el iniciar un verdadero proceso de descentralización. ${ }^{17}$

En materia de infraestructura, las vialidades se vieron poco afectadas. El Periférico, el Viaducto y el Circuito Interior no sufrieron daño alguno, sin embargo, el Eje Central Lázaro Cárdenas, avenida Juárez, avenida Chapultepec y Dr. Río de la Loza requirieron ser repavimentados en algunos tramos para garantizar inmediatamente el acceso al tránsito en la zona de catástrofe.

La red hidráulica fue seriamente dañada, lo cual alteró el normal suministro en varias colonias de las principales delegaciones afectadas: Cuauhtémoc, Venustiano Carranza, Benito Juárez, Gustavo A. Madero, Iztacalco, Coyoacán, Xochimilco, Tláhuac, Iztapalapa. Se detectaron 80 fugas en la red primaria y 1419 en la red secundaria (Comisión Metropolitana de Emergencia, Informe del 19 de octubre de 1985). El drenaje profundo, una de las principales y más costosas obras del Distrito Federal, prácticamente no tuvo problemas, las reparaciones que deberán realizarse se postergaron en el tiempo para ser realizadas en los meses de seca sin alterar el servicio normal. Del drenaje superficial, el de Río de la Piedad sufrió problemas, pero no dejó de funcionar y se llevará a cabo un programa de reparaciones. Finalmente, los transportes no sufrieron mayores daños; 13 de las 101 estaciones del metro estuvieron cerradas los días 19 y 20 de septiembre y el servicio de autobuses fue afectado en un 40 por ciento en esos mismos días, aunque inmediatamente se restableció el suministro y funcionó gratuitamente por varios días (Camarena, 1985).

El servicio más afectado fue el telefónico puesto que los daños que presentó han sido evaluados como los más graves "de la historia de la te-

17 Las modificaciones a las normas de construcción contenidas en los reglamentos vigentes fueron propuestas días después del terremoto por diferentes sectores sociales, habiendo dedicado la prensa atención particular a esta cuestión. Consulte La Jornada 24 y 25 de septiembre de 1985. El Dia en las mismas fechas. Sobre la descentralización existieron pronunciamientos - no siempre coincidentes- de prácticamente todos los sectores sociales del país y de los más elevados niveles de decisión (Excélsior 14 y 19 de octubre de 1985). El Dia del 1 de octubre de 1985 informaba: "Miguel de la Madrid afirma que la descentralización de la vida nacional es uno de los criterios básicos de nuestra política de desarrollo. Tendrá que ser acelerada y profundizada". Por su parte el Comité de Descentralización de la Comisión Nacional de Reconstrucción dio a conocer sus Acuerdos Básicos sobre la Descentralización el 28 de enero de 1985, consultar Excélsior de esa fecha. 
lefonía en el mundo". Las líneas locales con corte fueron 14500 , los servicios de larga distancia internacional se interrumpieron totalmente, 750 equipos múltiples destruidos, 6 centrales automáticas de larga distancia, 2 centrales Taudem, 3 centrales locales, 6 edificios y todos los centros de comunicación manual; quedaron sin energía $40 \%$ de los habitantes de la ciudad de México (Comisión Metropolitana de Emergencia, Informe del $19 / 10 / 85$ ).

En este contexto de emergencia, se privilegió la reconstrucción de escuelas y hospitales, tarea que se llevará a cabo con el dinero procedente del Fondo Nacional de Reconstrucción constituido con los aportes de ciudadanos, organizaciones nacionales y extranjeros y diferentes países. La vivienda popular constituye la otra gran prioridad y para ello se pusieron en marcha una serie de acciones y se adjudicó un importante monto de recursos del gobierno federal.

\section{LA POBLAGIÓN DAMNIFICADA}

Se dijo ya que el terremoto afectó principalmente a dos conjuntos sociales: 1) los trabajadores de menores ingresos que habitan las vecindades de las colonias del centro de la ciudad y 2) los trabajadores de ingresos medios que habitan condominios, ya sea conjuntos habitacionales administrados por el Estado o departamentos adquiridos en propiedad o en renta en el mercado privado de la vivienda.

No existe una fuente de información única que permita analizar las características socioeconómicas del conjunto de la población damnificada. La encuestra del IISUNAM, aplicada a las familias que se alojaron en campamentos y albergues, permite aproximarnos al universo de los ciudadanos de menores recursos económicos y sociales que debieron acudir a estas formas transitorias y públicas de alojamiento: los albergues y campamentos. ${ }^{18}$

El Sistema Integral de Información de Vivienda de sEDuE, por su parte, está llevando a cabo un Seguimiento y Control de la Atención a los damnificados que constituye una fuente de información complementaria. ${ }^{19}$

18 La Encuesta del irsunam fue coordinada por el Area de Sociología de la Población y Demogratía contando con la colaboración de 300 entrevistadores, dicha encuesta se llevó a cabo entre las familias e individuos que a partir del día 21 de septiembre se encontraban en albergues y campamentos ubicados en distintas delegaciones políticas. Informaciones periodisticas indicaban que se trataba de 30000 damnificados que se hallaban en 120 albergues y campamentos (véase Excélsior 14 de octubre de 1985).

19 La SEDUE registró al 20 de enero de 198617713 cédulas de las cuales 14083 habían sido canalizadas para su atención. De éstas el Sistema de Información de Atención a Damnificados había procesado al día 22 de enero 7093 cédulas, que constituye el universo que se presenta en este análisis. 
De esta población, el $52 \%$ se alojó con otra familia y el $32.96 \%$ permaneció en sus viviendas no obstante estar afectadas (cuadro núm. 2). Esto permite suponer que este registro capta al otro gran conjunto de damnificados: los que recurrieron a soluciones individuales para resolver transitoriamente sus necesidades de vivienda.

Por otra parte, mientras que la encuestra del insunam captó principalmente a la población damnificada de las delegaciones más afectadas - Cuauhtémoc y Venustiano Carranza- el registro de SEDUe, si bien expresa esta situación, incorpora también los requerimientos de una población más heterogénea, puesto que el $69.83 \%$ son habitantes de la delegación Cuauhtémoc, el $4.76 \%$ de la Venustiano Carranza y el resto proviene de las delegaciones Benito Juárez, Iztacalco e Iztapalapa.

a) La población damnificada de los campamentos y albergues

\section{- Inserción productiva}

El centro de la ciudad de México constituye un espacio de concentración de actividades económicas de diferente tipo. La pequeña industria, el comercio, los servicios públicos bancarios, seguros, financieros, oficinas, dan ocupación a un número muy amplio de trabajadores. Ciertamente, uno de los mayores atractivos de obtener una vivienda precaria en esta zona de la ciudad es la posibilidad de acceder a fuentes de trabajo de

\section{CUADRO 2}

UBICACION DE LOS DAMNIFICADOS - TOTALES

\begin{tabular}{lcc}
\hline Ubicación & Núms.absolutos & Porcentajes \\
\hline Sin dato & 294 & 3.86 \\
Albergue & 641 & 8.43 \\
Campamento & 209 & 2.75 \\
Con otra familia & 3956 & 52.00 \\
En vivienda afectada & 2507 & 32.96 \\
Totales & 7607 & 100.00 \\
\hline
\end{tabular}

fuente: sedue. Subsecretaría de Vivienda. Dirección General de Política y Coordinación de Programas de Vivienda. 
diferente tipo. Según el Censo de 1980, en la delegación Cuauhtémoc las actividades industriales absorben un $39.5 \%$ de la PEA, mientras que el sector terciario ocupa el $55.7 \%$ de la PEA.

Para la delegación Venustiano Carranza la situación no varía demasiado, representando el secundario el 33.1 y el terciario el 60.6 por ciento. Es importante destacar que ambas delegaciones concentran en sus respectivos territorios un porcentaje de actividades del terciario superior al promedio que registra el DF (52.1 por ciento). Esto permite confirmar que el área central continúa ofreciendo alternativas ocupacionales a un importante contingente de trabajadores que poseen un bajo grado de calificación ocupacional y que sin embargo logran realizar alguna actividad remunerada y sobrevivir en el medio urbano. Según la encuesta del nsuNAM, para los damnificados de menores recursos las empresas privadas constituyen las principales opciones ocupacionales, particularmente para los más jóvenes (de 12 a 34 años). Las posibilidades de poseer un negocio propio se incrementan con la edad. Los vendedores ambulantes constituyen un número muy importante de la población encuestada, mientras que aproximadamente sólo un 10 por ciento de la población masculina desempeña actividades en el sector gubernamental. Si consideramos la posición que ocupan en el empleo los más jóvenes, éstos se desempeñan en el sector privado como empleados en un 38.6 por ciento, mientras que en un $15.2 \%$ son obreros. Los jefes de familia de más de 35 años son en una alta proporción (33.6\%) trabajadores por cuenta propia; presumiblemente, se trata de pequeños propietarios con escaso capital.

En el caso de las mujeres, la situación ocupacional se caracteriza porque si bien las empresas privadas absorben la mayor parte de la mano de obra femenina, desempeñándose como empledas (35.4 por ciento para las de 12-34 años, 30.5 por ciento para las de 35-64 y 10.9 por ciento para las de más de 65 años), el $20.6 \%$ de las trabajadoras del sector privado más jóvenes son obreras y un $23.9 \%$ de las de $35-64$ años también. Para las mujeres de más de 35 años y (menos de 65) la principal actividad, en cambio, es el trabajar por su cuenta como vendedoras ambulantes (36.1 por ciento trabaja por su cuenta y de este porcentaje el 88.9 son vendedoras ambulantes). Es decir, la fuerza de trabajo femenina recorre una trayectoria ocupacional similar a la de los hombres, puesto que para los más jóvenes - los que han accedido a un nivel de escolaridad por lo menos elemental - las posibilidades de incorporación a actividades típicamente capitalistas se incrementan notablemente, mientras que los de mayor edad deben hallar alguna actividad por cuenta propia.

- Nivel de ingreso

En cuanto al nivel de ingreso, las familias cuyos jefes de hogar son hombres (entre los 35 y 64 años de edad) son las que presentan mejores 
remuneraciones. Entre estos trabajadores, sólo un 20 por ciento gana menos de un salario mínimo, porcentaje éste que se incrementa a $29.5 \%$ cuando el jefe de hogar es mujer (cuadro núm. 3).

\section{CUADRO 3}

INGRESO FAMILIAR SEGÚN EL JEFE DE HOGAR, SEA HOMBRE O MUJER (en porcentajes)

\begin{tabular}{|c|c|c|c|c|c|c|}
\hline \multirow{2}{*}{$\begin{array}{l}\text { Num. de veces } \\
\text { salario minimo }\end{array}$} & \multicolumn{6}{|c|}{$E d a d$} \\
\hline & $12-34$ & 35.64 & 65.98 & $12-34$ & $35-64$ & 65.98 \\
\hline Menos de 0.5 & 8.1 & 7.5 & 15.1 & 18.1 & 15.0 & 28.6 \\
\hline 0.5 a 0.9 & 14.8 & 13.3 & 16.4 & 17.3 & 14.5 & 11.4 \\
\hline 1.0 & 15.3 & 11.3 & 4.4 & 16.9 & 8.5 & 5.7 \\
\hline 1 a 1.4 & 12.7 & 9.7 & 10.1 & 8.6 & 9.1 & 7.1 \\
\hline 1.5 a 1.9 & 12.1 & 10.2 & 10.7 & 7.0 & 8.9 & 2.9 \\
\hline 2 a 2.9 & 9.9 & 13.7 & 5.0 & 7.8 & 11.8 & 7.1 \\
\hline 3 y más & 7.1 & 12.2 & 11.3 & 4.1 & 11.0 & 7.2 \\
\hline No especificaron & 20 & 22.1 & 27.0 & 20.2 & 21.2 & 30.0 \\
\hline Totales & $\begin{array}{c}100 \\
(873)\end{array}$ & $\begin{array}{r}100 \\
(1151)\end{array}$ & $\begin{array}{c}100 \\
(159)\end{array}$ & $\begin{array}{c}100 \\
(243)\end{array}$ & $\begin{array}{c}100 \\
(552)\end{array}$ & $\begin{array}{l}100 \\
(70)\end{array}$ \\
\hline
\end{tabular}

FUENTE: Encuesta a damnificados, ISUNAM (1985).

Para las familias más jóvenes o de más edad, sobre todo en las que las mujeres son las responsables del hogar, las dificultades económicas son aún mayores. Entre los jefes de hogar (entre 21 y 34 años) una tercera parte gana menos del salario mínimo, porcentaje que se eleva al 35.4 por ciento cuando las responsables del mantenimiento del hogar son mujeres de la misma edad. De los hombres y mujeres de mayor edad (65 a 98 años), alrededor de un $30 \%$ no alcanza a obtener una remuneración próxima al mínimo fijado por la ley.

Lo que estos datos confirman es que la mayoría de estas familias carece de derechos laborales para acceder a un crédito o a una vivienda de las ofrecidas por los fondos habitacionales (INFONAVIT o FOviSSSTE); sólo una cuarta parte de las familias cuyo jefe tiene entre 35-64 años estaría 
en condiciones de acceder a ese tipo de financiamiento. Como se trata de no asalariados de muy bajos ingresos, el único organismo gubernamental que contempla sus necesidades es FONHAPO, organismo con limitados recursos para enfrentar este problema con la urgencia que se demanda. La creación de un nuevo organismo (Renovación Habitacional Popular) pretende cubrir las necesidades de los damnificados de menores recursos.

\section{- Tipo de vivienda y forma de tenencia}

Como ya se dijo, la situación habitacional de las colonias populares del centro de la ciudad de México eran ya muy deficientes antes de que se produjeran los sismos. El hacinamiento, la insalubridad, la deficiencia en la provisión de los principales servicios habitacionales (agua, drenaje) son características que compartía el conjunto de las vecindades. Es decir, el sismo vino a agudizar un deterioro habitacional existente. No puede decirse lo mismo respecto al acceso al equipamiento (educación, salud, recreación, con excepción de espacios verdes adecuados a las necesidades) y el transporte público que hacen de esta área central una zona de la ciudad muy bien dotada.

Algunos datos contenidos en la encuesta del issunam permiten confirmar algunas de estas características de la vivienda de los estratos más pobres de la población. Considerada globalmente, la población que recurrió a campamentos y albergues en el momento del terremoto provenía en su mayoría de vecindades ( $60.2 \%$ de las familias encuestadas). El $21.7 \%$ habitaba en departamentos, el $9 \%$ en cuartos de azotea, el $4.8 \%$ en viviendas colectivas (hoteles, pensiones), y el 3.8\% en casa sola (cuadro núm. 4). Considerando la situación de las dos principales delegaciones afectadas, puede observarse que en el caso de la Cuauhtémoc, un 53.5 por ciento de la población vivía en vecindades, prácticamente en su totalidad rentadas; de estas viviendas, una cuarta parte aproximadamente se hallaba bajo el régimen de renta congelada (cuadro núm. 5). En el caso de la delegación Venustiano Carranza, las vecindades representan las tres cuartas partes de las viviendas de los damnificados (74.6\%), mientras que la forma de tenencia es similar (cuadro núm. 6). En la delegación Cuauhtémoc, el $26.6 \%$ de los encuestados que vivían con anterioridad al sismo en departamentos, aproximadamente un $12 \%$ eran propietarios. Las deterioradas vecindades son una opción habitacional que, frente a otras alternativas (incluso los cuartos de azotea), es comparativamente ventajosa para los escasos recursos que presentan la mayor parte de estas familias.

\section{- Condiciones de habitabilidad}

El 52.8 por ciento del total de los encuestados habitaba en viviendas de un solo cuarto, mientras que el 27.1 lo hacía en viviendas de dos y el 


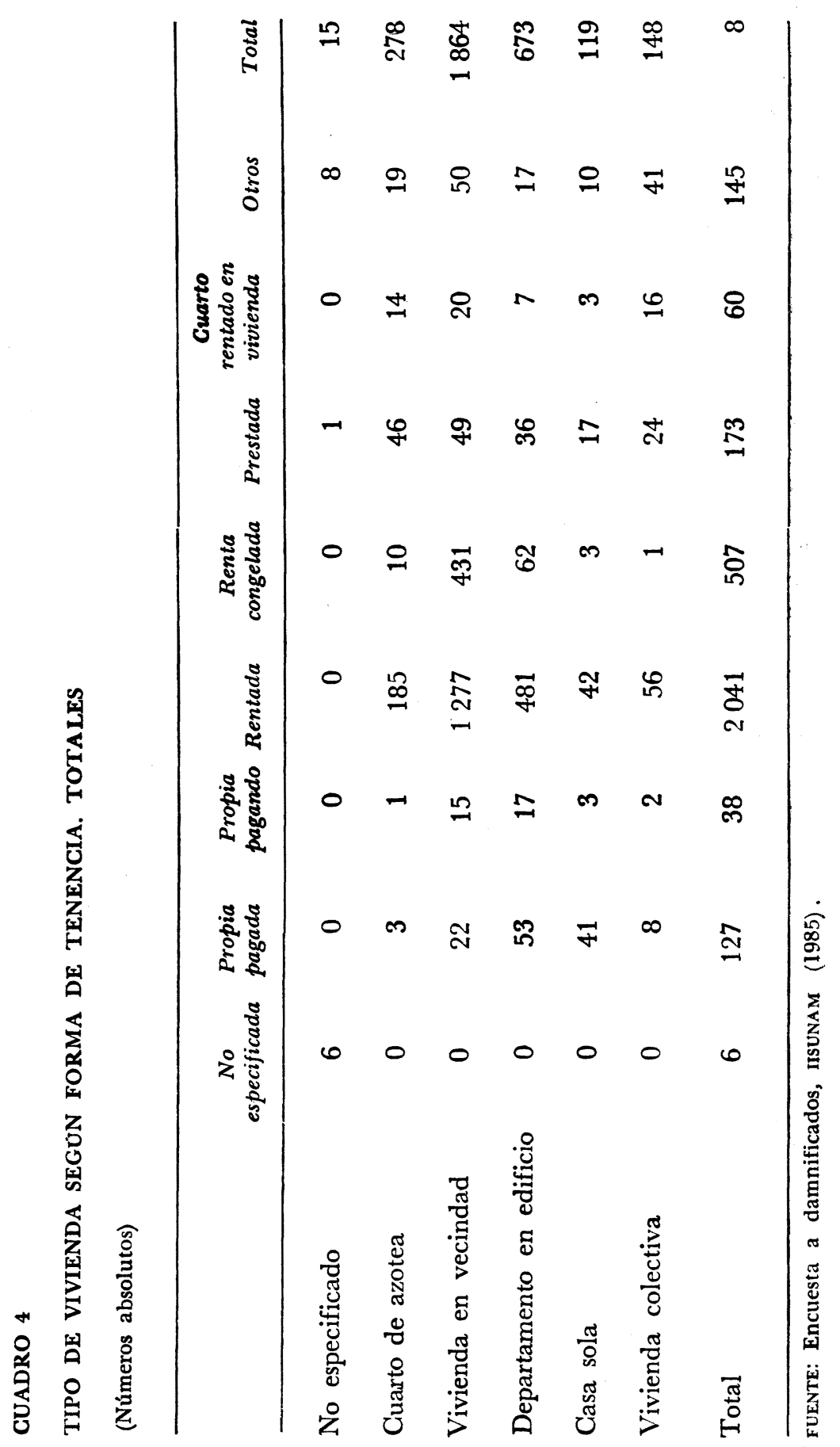


CUADRO 5

TIPO DE VIVIENDA, SEGUN FORMA DE TENENCIA

DELEGACION CUAUHTEMOC

(Números absolutos)

\section{Propia Propia Renta tado en \\ pagada pagando Rentada congelada Prestada vivienda Otros Total}

No espe-

cificado

0

10

1

Cuarto

en azotea

$2 \quad 0 \quad 141$

$8 \quad 38$

10

$16 \quad 215$

Vivienda

en vecindad

Departamento

en edificio

46

$16 \quad 316$

38

29

$\begin{array}{lll}5 & 15 & 465\end{array}$

Casa sola

$7 \quad 1$

16

0

8

1

4

37

Vivienda

colectiva

11

41

1

5

8

27

94

Total

FUENTE: Encuesta a damnificados, IISUNAM (1985).

10.2 de tres cuartos. Esos datos reflejan la situación de alto grado de hacinamiento prevaleciente, puesto que las familias encuestadas se componen en promedio de más de 5 miembros.

Por otra parte, las condiciones son realmente precarias y evidencian una absoluta falta de inversión en mantenimiento. Sin embargo, sólo el $11.5 \%$ del total de las viviendas de las familias encuestadas se derrumbó, mientras que la mayoría, prácticamente las tres cuartas partes, presentaba peligro o derrumbes parciales (cuadro núm. 7). 


\section{CUADRO 6}

TIPO DE VIVIENDA, SEGÚN FORMA DE TENENCIA

DELEGACIÓN VENUSTIANO CARRANZA

(Números absolutos)

\section{Propia Propia Renta Cuartoren}

pagada pagando Rentada congelada Prestada vivienda Otros Total

\begin{tabular}{lrrrrrrrr}
\hline $\begin{array}{l}\text { Cuarto } \\
\text { de azotea }\end{array}$ & 0 & 1 & 23 & 2 & 3 & 4 & 1 & 34 \\
$\begin{array}{l}\text { Vivienda } \\
\text { en vecindad }\end{array}$ & 14 & 11 & 531 & 187 & 24 & 5 & 17 & 789 \\
$\begin{array}{l}\text { Departamento } \\
\text { en edificio }\end{array}$ & 2 & 0 & 125 & 20 & 3 & 0 & 0 & 150 \\
$\begin{array}{l}\text { Casa sola } \\
\text { Vivienda }\end{array}$ & 22 & 1 & 18 & 1 & 4 & 0 & 2 & 48 \\
$\begin{array}{l}\text { colectiva } \\
\text { Sin especificar }\end{array}$ & 7 & 1 & 10 & 0 & 3 & 6 & 8 & 35 \\
Total & 45 & 14 & 707 & 210 & 37 & 15 & 29 & 1057 \\
\hline
\end{tabular}

FUENTE: Encuesta a damnificados, IISUNAM (1985) .

\section{CUADRO 7}

TIPO DE VIVIENDA SEGÚN MOTIVO DE ABANDONO-TOTAL

(Números absolutos)

\begin{tabular}{lccccccr}
\hline & $\begin{array}{c}\text { Sin } \\
\text { especificar }\end{array}$ & $\begin{array}{c}\text { Derrumbe } \\
\text { total }\end{array}$ & $\begin{array}{c}\text { Derrumbe } \\
\text { parcial }\end{array}$ & $\begin{array}{c}\text { Peligro } \\
\text { derrumbe }\end{array}$ & $\begin{array}{c}\text { Zona de } \\
\text { peligro }\end{array}$ & Otrios & Total \\
\hline $\begin{array}{l}\text { No especificado } \\
\begin{array}{l}\text { Cuarto } \\
\text { de azotea }\end{array}\end{array}$ & 6 & 0 & 0 & 1 & 0 & 0 & 7 \\
$\begin{array}{l}\text { Vivienda } \\
\text { en vecindad }\end{array}$ & 1 & 31 & 41 & 129 & 74 & 2 & 278 \\
$\begin{array}{l}\text { Departamento } \\
\text { en edificio }\end{array}$ & 3 & 214 & 300 & 1164 & 133 & 40 & 1864 \\
$\begin{array}{l}\text { Casa sola } \\
\begin{array}{l}\text { Vivienda } \\
\text { colectiva }\end{array}\end{array}$ & 1 & 75 & 92 & 410 & 82 & 11 & 673 \\
Total & 0 & 17 & 19 & 65 & 10 & 4 & 119 \\
\hline
\end{tabular}

FUENTE: Encuesta a damniticados, IISUNAM (1985). 


\section{- Gastos por vivienda}

El nivel de rentas en la Cuauhtémoc es comparativamente muy bajo, puesto que poco más de una cuarta parte $(27.1 \%)$ de las familias que habitaban las vecindades pagaban menos de 1000 pesos mensuales; una proporción similar $(27.3 \%)$ pagaban entre 1000 y 3000 pesos; un $14.9 \%$ de 3000 a 5000 pesos; un $15.4 \%$ de 5000 a 9000 pesos. Es decir, prácticamente la totalidad paga menos de 10000 pesos (cuadro núm. 8).

En el caso de la Venustiano Carranza, el 29.3\% pagaba menos de 1000 pesos, el $19.9 \%$ entre 1000 y 3000 pesos; el $20.9 \%$, entre 3000 y 5000 pesos y el $13.1 \%$ entre 5000 y 9999 pesos. Es decir, también en este caso prácticamente la totalidad de los habitantes de las vecindades pagaban menos de 10000 pesos de renta (cuadro núm. 9).

Esta situación es similar en el caso de los cuartos de azotea. En el caso de los departamentos, las rentas lógicamente son más elevadas. En la delegación Cuauhtémoc que es la que concentra el mayor número de encuestados en este tipo de vivienda, el $21.1 \%$ pagaba menos de 5000 pesos; el $17.6 \%$ pagaba entre 5000 y 9999 ; el $18.5 \%$ entre 10000 y 19999 pesos y el $10.5 \%$ entre 20000 y 39999 pesos. Las rentas de los departamentos de la Venustiano Carranza en un $26.7 \%$ oscilaban entre 5000 y 9999 pesos y el 29.3\% entre 10000 y 19000 pesos. Sin embargo, prácticamente la otra mitad de las familias encuestadas pagaba menos de 5000 pesos mensuales.

Es decir, uno de los principales obstáculos que deberá enfrentar el proceso de reconstrucción es la limitada capacidad de pago de estas familias. La opción por la vecindad o cualquier otra vivienda precaria es uno de los componentes claves de la estrategia de sobrevivencia que poseen las clases populares en el medio urbano. Destinar un bajo porcentaje del ingreso familiar a gastos habitacionales permite garantizar otros consumos indispensables, particularmente alimentación.

\section{b) La población damnificada que optó por una solución individual}

\section{- Inserción productiva}

Los datos del Sistema de Información y Vivienda de sEDUE permiten aproximarnos a las familias de damnificados que hallaron otra opción habitacional transitoria, al alojarse con familiares o continuar en viviendas afectadas. En este conjunto social, considerado globalmente, prácticamente la mitad son trabajadores que desempeñan alguna actividad en el sector público (47.50\% del total de los registrados) (cuadro núm. 10). Estas proporciones se elevan en el caso de los habitantes del multifamiliar Juárez, en cuyo caso en su totalidad son trabajadores al servicio del Estado: poco menos de las tres cuartas partes en actividad, un 13.94\% jubilados y $11.95 \%$ de pensionados, los cuales presumiblemente son ex-trabajadores o sus familiares. 


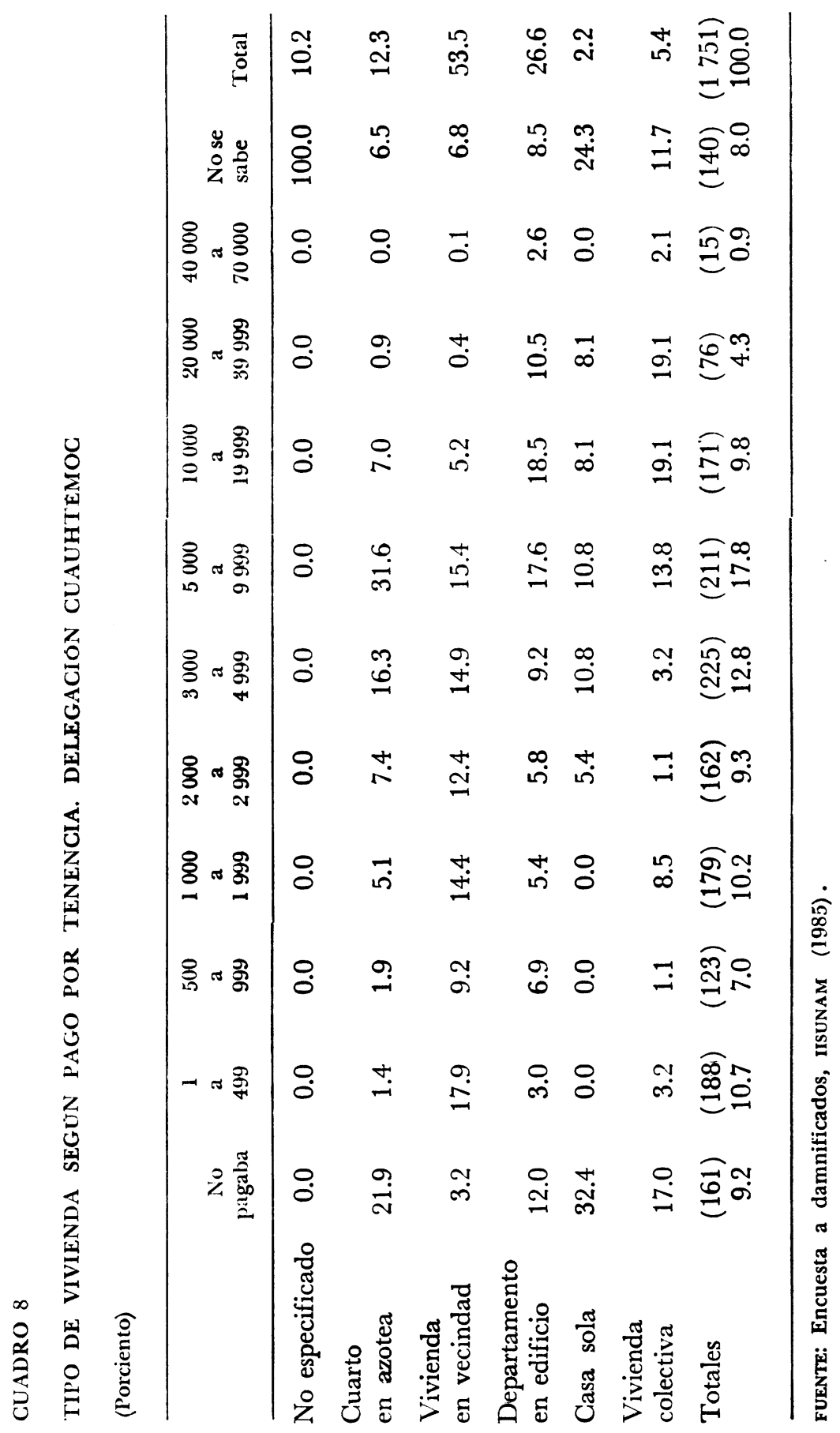




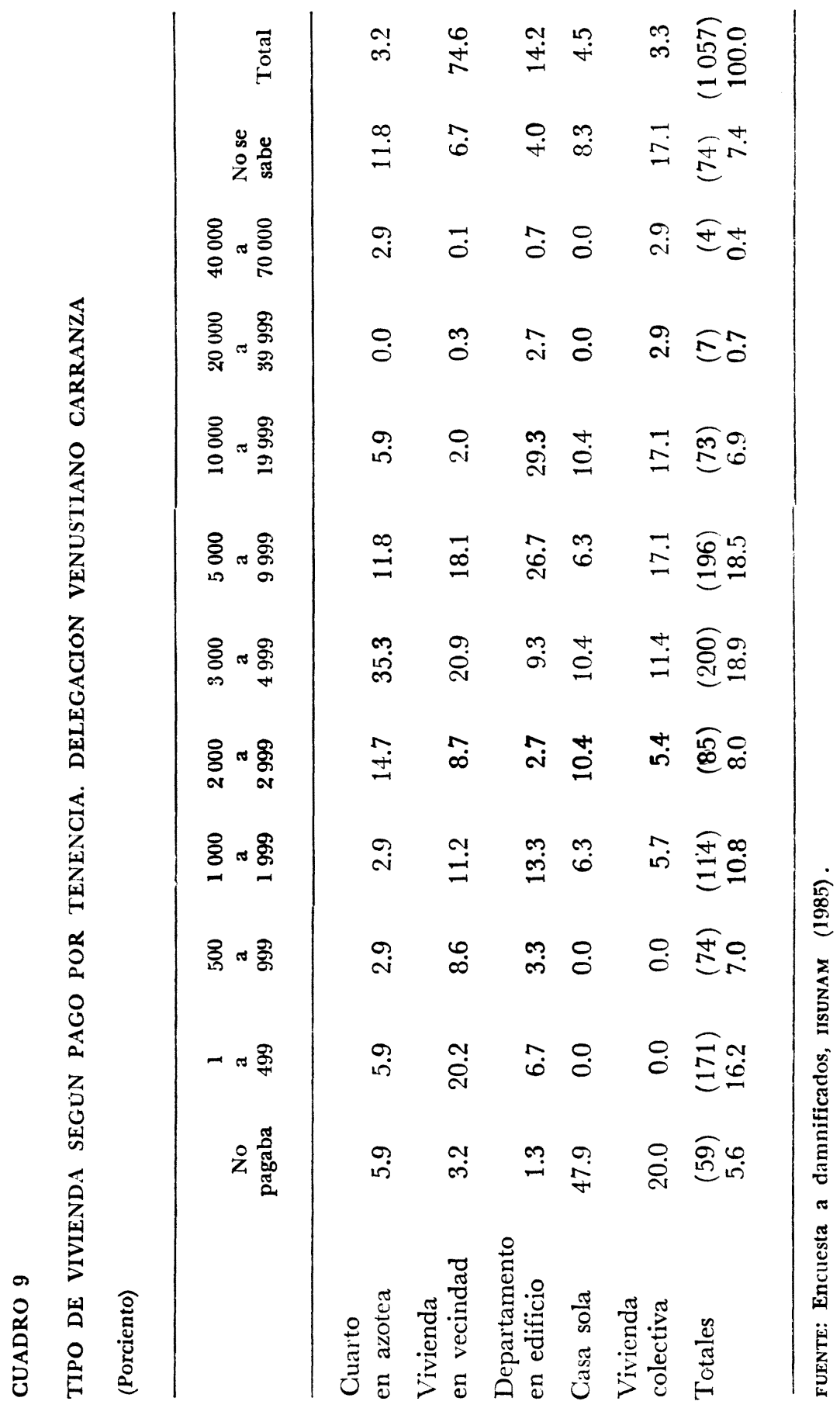


CUADRO 10

DAMNIFICADOS: POSICION EN EL TRABAJO-TOTALES

\begin{tabular}{lrr}
\hline Posición en el trabajo & Núms. absolutos & Porcentajes \\
\hline Sin dato & 92 & 1.21 \\
Patrón & 138 & 1.81 \\
Obrero & 166 & 2.18 \\
Sector Privado & 2320 & 30.50 \\
Sector Público & 3613 & 47.50 \\
Independiente & 918 & 12.07 \\
Pensionado & 197 & 2.59 \\
Jubilado & 119 & 1.56 \\
Hogar & 23 & .30 \\
Desempleado & 21 & .28 \\
Totales & 7607 & 100.00 \\
\hline
\end{tabular}

Fuente: SEdue. Subsecretaría de Vivienda. Dirección General de Política y Coordinación de Programas de Vivienda.

Para esta misma población, el sector privado es la otra fuente de empleo principal. Este sector de damnificados es, en un elevado porcentaje de "acreditados" de los fondos habitacionales (INFONAVIT) para el sector privado y (FOvisSSTE) para el sector público, lo que les permite acceder a un crédito o a una vivienda de la que ofrecen estos organismos de vivienda. Esta posibilidad, como se vio, es mucho menor para el caso de las familias de menores recursos que se alojaron en albergues o campamentos.

\section{- Nivel de ingreso}

La población captada por el registro de sEDUE, considerada globalmente, presenta un ingreso mayor que el considerado por la encuesta del insunam. Sólo el $10.31 \%$ de las familias reúne menos del salario mínimo. La mayoría (el $48.8 \%$ ) gana entre 1.01 y 3.0 veces el salario mínimo y otro 40.89\% gana más de tres veces el salario mínimo (cuadro núm. 11).

Es posible advertir que la distribución de los niveles de ingreso familiar es diferente según el lugar de procedencia. Los damnificados de Tlatelolco en un $61.47 \%$ presentan ingresos superiores 3 veces al salario mínimo (cuadro núm. 12), mientras que los del multifamiliar Benito Juá- 
POLÍTICA DE VIVIENDA

CUADRO 11

DAMNIFICADOS: ESTRATOS SALARIALES - TOTALES

\begin{tabular}{lcc}
\hline Veces salario minimo & Núms. absolutos & Porcentajes \\
\hline 0.00 & 264 & 3.47 \\
0.01 a 0.50 & 43 & .57 \\
0.51 a 1.00 & 477 & 6.27 \\
1.01 a 1.50 & 770 & 10.12 \\
1.51 a 2.00 & 1186 & 15.59 \\
2.01 a 2.50 & 996 & 13.09 \\
2.51 a 3.00 & 761 & 10.00 \\
3.01 a 4.00 & 1288 & 16.93 \\
4.01 a 5.00 & 698 & 9.18 \\
5.01 a 6.00 & 448 & 5.89 \\
6.01 y más & 676 & 8.89 \\
Totales & 7607 & 100.00
\end{tabular}

Fuente: SfDuf. Subsecretaría de Vivienda. Dirección General de Política y Coordinación de Programas de Vivienda.

CUADRO 12

DAMNIFICADOS: ESTRATOS SALARIALES - TLATELOLCO

\begin{tabular}{lcc}
\hline Veces salario minimo & Núms. absolutos & Porcentajes \\
\hline 0.00 & 36 & 4.01 \\
0.01 a 0.50 & & \\
0.51 a 1.00 & 19 & 2.12 \\
1.01 a 1.50 & 51 & 5.68 \\
1.51 a 2.00 & 62 & 6.90 \\
2.01 a 2.50 & 95 & 10.58 \\
2.51 a 3.00 & 83 & 9.24 \\
3.01 a 4.00 & 171 & 19.04 \\
4.01 a 5.00 & 102 & 11.36 \\
5.01 a 6.00 & 90 & 10.02 \\
6.01 y más & 189 & 21.05 \\
Totales & 898 & 100.00 \\
\hline
\end{tabular}

Fuente: Sedue. Subsecretaría de Vivienda. Dirección General de Política y Coordinación de Programas de Vivienda. 
rez sólo en un $31.2 \%$ se ubican en esa franja de ingreso. Una cuarta parte de la población del Juárez, en cambio, gana menos del salario mínimo, cuestión ésta que debe atribuirse no sólo a los más bajos salarios de los trabajadores incorporados a una actividad remunerada en el sector público sino también a la alta proporción de jubilados y pensionados que vivían en ese conjunto habitacional (cuadro núm. 13).

CUADRO 13

DAMNIFICADOS: ESTRATOS SALARIALES - MULTIFAMILIAR

BENITO JUAREZ

\begin{tabular}{|c|c|c|}
\hline Veces salario minimo & Núms. absolutos & Porcentajes \\
\hline 0.00 & 23 & 5.09 \\
\hline 0.01 a 0.50 & 1 & 0.22 \\
\hline 0.51 a 1.00 & 85 & 18.81 \\
\hline 1.01 a 1.50 & 31 & 6.86 \\
\hline 1.51 a 2.00 & 80 & 17.70 \\
\hline 2.01 a 2.50 & 58 & 12.83 \\
\hline 2.51 a 3.00 & 33 & 7.30 \\
\hline $3.01 \mathrm{a} 4.00$ & 71 & $15.71^{\prime}$ \\
\hline 4.01 a 5.00 & 37 & 8.19 \\
\hline 5.01 a 6.00 & 15 & 3.32 \\
\hline 6.01 y más & 18 & 3.98 \\
\hline Totales & 452 & 100.00 \\
\hline
\end{tabular}

fuente: sedue. Subsecretaría de Vivienda. Dirección General de Politica y Coordinación de Programas de Vivienda.

\section{- Tipo de vivienda y forma de tenencia}

La población atendida por SEDUE pertenece a los sectores medios que vivían en condominios administrados por el Estado u obtenidos por mecanismos tradicionales de mercado (alquiler o compra). Las alternativas que ahora ofrece el Estado a estas familias son: 1) una vivienda localizada en la periferia de la ciudad, 2) un crédito financiero por los fondos habitacionales. En ambos casos se trata de condiciones crediticias sumamente favorables puesto que el interés es del $4 \%$ y a plazos muy prolongados. La tolerancia en el pago inicial, así como la reducción de gastos administrativos por compra, disminuye notablemente el precio de estas viviendas para los damnificados. Sin embargo, el $79.09 \%$ de esta pobla- 
ción habitaba una vivienda en alquiler; sólo el $15.41 \%$ era propietaria y el $4.43 \%$ declaró poseerla en préstamo (cuadro núm. 14). En el caso de Tlatelolco, la proporción de propietarios es mayor, representando un $50.22 \%$ de los encuestados y, como contrapartida, los vecinos del Multifamiliar Juárez en su totalidad rentan, puesto que es parte de una prestación que el IsSSTE ofrecía a sus trabajadores.

CUADRO 14

DAMNIFICADOS: FORMA DE TENENCIA DE LA VIVIENDA-TLATELOLCO

\begin{tabular}{lcc}
\hline Tenencia & Núms.absolutos & Porcentajes \\
\hline Sin dato & 82 & 1.08 \\
Propia & 1172 & 15.41 \\
Rentada & 6016 & 79.09 \\
Prestada & 337 & 4.43 \\
Totales & 7607 & 100.00 \\
\hline
\end{tabular}

fuente: Sedue. Subsecretaría de Vivienda. Dirección General de Política y Coordinación de Programas de Vivienda.

CUADRO 15

DAMNIFICADOS FORMA DE TENENCIA DE LA VIVIENDA-TLATELOLCO

\begin{tabular}{lcc}
\hline Tenencia & Núms. absolutos & Porcentajes \\
\hline Sin dato & 15 & 1.67 \\
Propia & 451 & 50.22 \\
Rentada & 357 & 39.76 \\
Prestada & 75 & 8.35 \\
Totales & 898 & 100.00 \\
\hline
\end{tabular}

fuente: Sedue. Subsecretaría de Vivienda. Dirección General de Política y Coordinación de Programas de Vivienda.

- Condiciones de habitabilidad

Prácticamente el $40 \%$ de la población atendida por sEDUE qued6́ sin vivienda por haberse destruido totalmente la que habitaba. 
En cuanto a las características de estas viviendas, debe pensarse que en el caso de las administradas por el Estado, carecían de un mantenimiento adecuado a las necesidades que presentaban los edificios. En el caso del multifamiliar Juárez, los gastos de mantenimiento correspondían al gobierno, que actuaba directamente como casero. En Tlatelolco, formas de propiedad no claramente definidas y desacuerdos entre usuarios e instituciones son algunas de las causas del deterioro que presentaba un considerable número de edificios que constituían un conjunto de más de 100. A ello se agregaron otras, como los cambios de uso que afectaron las condiciones de seguridad de los mismos. La existencia de bodegas y oficinas en construcciones originariamente destinadas a usos habitacionales y la ocupación de las azoteas con viviendas en renta para sectores de muy bajos ingresos eran hechos conocidos públicamente. Así, en el caso de Tlatelolco el $67.93 \%$ de la población perdió totalmente su vivienda, razón por la cual las instituciones gubernamentales debieron dar una respuesta particular a las organizaciones de vecinos que representan a estos habitantes del conjunto habitacional. La forma de actuación del Estado frente a esta situación se analizará seguidamente en el marco del Programa Emergente de Vivienda elaborado por la senue.

\section{LA POLÍtica habitaGional de REconstrucGión}

Las formas mediante las cuales las instituciones del Estado debieron enfrentar la situación de desastre que se generó en relación con la destrucción parcial o total de vivienda fueron diferentes en función de: 1) los destinatarios de la acción pública - sectores populares que habitaban vecindades o capas medias que vivían en condominios- y 2) los organismos gubernamentales involucrados (SEDUE, DDF, FONHAPO, Renovación Habitacional Popular, INFONAvit, fovissste, AURIS). La acción estatal se inició con el saldo negativo que arrojaban los daños en varios conjuntos habitacionales administrados por el gobierno. El derrumbe del edificio Nuevo León en Nonoalco Tlatelolco ocasionó la trágica muerte de alrededor de un millar de personas. A ello se agregaban daños que presentaban algunos edificios del Multifamiliar Juárez y otros conjuntos de vivienda de interés social en los que si bien no hubo víctimas, debieron ser desalojados para su reparación. Los efectos de un desastre natural ponían en evidencia los problemas urbanos generados durante una década de actuación del Estado en materia de política de vivienda popular. Lo que quedó en cuestión fue precisamente la forma como el Estado había consagrado su participación en la resolución del problema habitacional: la construcción de condominios en gran escala.

El Departamento del Distrito Federal y la sedue tomaron a su cargo la organización de una acción pública a la cual las diferentes instituciones 
de vivienda se incorporaron ofreciendo personal, recursos económicos, viviendas o créditos disponibles, con lo que se generaron opciones para atender inmediatamente a los damnificados. El problema en materia habitacional se enmarcó en el intento gubernamental de atender prioritariamente un conjunto más amplio de problemas (salud, transporte, comunicaciones), entre los que el salvamento de vidas humanas era el fundamental. La forma como el Estado actuó fue de diferente tipo y persiguió distintos objetivos:

1) Se crearon espacios abiertos al debate y a la opinión pública, diferentes comisiones en las que se invitó a participar especialmente a representantes de diferentes instituciones (educacionales, culturales, de gobierno, etcétera) y organizaciones (cámaras, agrupaciones de profesionales, etcétera).

2) Se institucionalizó la negociación efectiva entre los organismos gu: bernamentales y los damnificados. La sEDUE fue el principal convocante de organizaciones de vecinos de los principales conjuntos habitacionales de los sectores medios, mientras que el DDF y luego Renovación Habitacional Popular asumieron la relación directa con los vecinos de las colonias populares del centro de la ciudad.

3) Se efectuó una acción inmediata de ayuda a la población damnificada; provisión de elementos indispensables tales como albergue temporal, alimentación, vestuario, atención médica y se organizó la atención de las demandas habitacionales.

\section{a) Los espacios de opinión}

El 3 de octubre de 1985 se creó la Comisión Nacional de Reconstrucción

como órgano de consulta y participación en las acciones que los sectores público, social y privado realicen en el ámbito nacional para enfrentar y resolver los problemas causados por los movimientos sísmicos recientes (Comisión Nacional de Reconstrucción, octubre, 1985, página 11).

Formando parte de la misma, se creó también un Comité de Auxilio Social presidido por el presidente de la República, los secretarios de Educación Pública, Salud, Trabajo y Desarrollo Urbano y Ecología, e integrado por representantes de la Federación de Trabajadores al Servicio del Estado, el Congreso del Trabajo, la Confederación Nacional Campesina, agrupaciones empresariales y de educación superior y organizaciones representativas del sector social (las organizaciones de damnificados, en 
cambio, estaban ausentes) ${ }^{20}$ Su función era atender las tareas de reconstrucción en áreas consideradas prioritarias: educación, salud, empleo y vivienda. Esto dio origen a la formación de una Coordinación de Vivienda que actuaría en el interior de dicho comité. El propósito fundamental de esta Coordinación de Vivienda fue expresado como el de:

"atender las necesidades de vivienda de los damnificados del sismo, apoyando la autoconstrucción y reparación y teniendo como prioridad la atención de las necesidades de las clases populares" (Comisión Nacional de Reconstrucción, octubre, 1985, pág. 5).

Las funciones de la Coordinación de Vivienda, según fueron enunciadas en el acuerdo del titular del Ejecutivo Federal del 14 de octubre eran: a) Estudiar y proponer estrategias y acciones para la solución de las necesidades de vivienda e infraestructura básica de los damnificados del sismo, teniendo como prioridad las clases populares y $b$ ) Analizar y proponer políticas y medidas para una solución integral de la vivienda en relación con: el medio urbano, la descentralización y el desarrollo regional; la comunidad y los servicios; la modalidad de promoción y reglamentación a la vivienda; tierra, técnicas e insumos para la misma, calidad ambiental; desarrollo de la comunidad y servicios y mecanismos financieros para su realización.

En su interior se formaron diez subcoordinaciones, grupos de trabajo que, sobre diferentes temáticas, se encargaron de analizar otros tantos aspectos de la problemática habitacional: vivienda y suelo, mecanismos financieros, modalidades de promoción y reglamentación, calidad ambiental, comercio y vivienda, espacios educativos, ciudades dormitorio, técnicas en insumos, traslado de vivienda. ${ }^{21}$ En la ceremonia de instalación de la Coordinación de Vivienda el 14 de octubre de 1985 en el Auditorio de la sEDUE, el titular de esta dependencia expresó:

"Se revisará y evaluará la acción del Estado en materia de vivienda, por ello distinguidos mexicanos forman parte del Consejo Consultivo. Tomaremos de las tecnologías extranjeras lo que mejor corresponda a nuestra realidad, de ahí que se haya invitado a participar a promotores, a centros de enseñanza superior, a los gremios de profesionales y a los usuarios. Se discutirán esquemas de financiamiento y de comercialización, la presencia de personalidades en este campo así lo atestigua. En suma no habrá

20 Desde el inicio la forma como las distintas instituciones de gobierno se vincularon con la población afectada fue a través de reconocer las demandas individuales, las de un conjunto de viviendas de determinada vecindad, las de los damnificados de determinados conjuntos habitacionales. La prensa registró la forma como los más altos niveles de dirección atendían estas demandas, y debían reconocer a sus representantes. Cfr. Unomásuno, 22 de noviembre de 1985. Sin embargo, los damnificados presentaron desde el principio la estrategia de que la Coordinadora Unica de Damnificados fuese reconocida como el principal interlocutor. Cfr. Unomásuno del 28 de noviembre de 1985.

21 Excelsior, 15 de octubre de 1985. 
campo de actividad que no se toque ni voz que no sea escuchada" (Comisión Nacional de Reconstrucción, octubre, 1985, pág. 20).

Efectivamente, dichos espacios fueron constituidos por representantes de diferentes organismos públicos y privados y en algunos casos se publicó en los periódicos capitalinos su convocatoria. La intención oficial era la de abrir canales de expresión en diferentes niveles y las comisiones se constituyeron en ámbitos formales de participación, a partir de los cuales podían lograrse dos objetivos: 1) conocer la opinión y los intereses de distintos sectores sociales que participan en la cuestión habitacional a fin de elaborar propuestas consensualmente aceptadas, y 2) generar una legitimidad social amplia sobre la actuación gubernamental.

En la producción formal de la vivienda popular ${ }^{22}$ participa un conjunto de agentes sociales con intereses difíciles de conciliar; hacer efectiva la reconstrucción implicaba gestar compromisos sociales con cada uno. Tanto la Cámara Nacional de la Industria de la Construcción (GNIC), como los representantes de los llamados promotores de vivienda, expresaron su apoyo a la constitución de la Coordinación, así como la forma en que evaluaba el problema desde su óptica. El impulso que seguramente adquiría la actividad constructora, afectada negativamente por la crisis, generaba expectativas favorables entre estos empresarios. El presidente de la cNIC expresó diferentes formas de compromiso que asumirían los empresarios, diciendo que la industria que representaba:

"daría su apoyo incondicional y como muestra puedo afirmar que las constructoras pertenecientes a la Cámara, nos han participado que están dispuestas a entregar todas sus construcciones disponibles a quien el gobierno indique, con el solo pago de un enganche reducido, como nos indicó Don Fernando Solana. $\underline{Y}$ nos indican poderlas terminar antes de un mes... En la mism aforma estamos en contacto con las autoridades de SEDUE para lograr que todos los costos adicionales a la vivienda sean reconocidos por las partes que intervienen y la Cámara ofrece que sus constructores no cobrarán ninguna utilidad en las viviendas de emergencia" (Comisión Nacional de Reconstrucción, octubre, 1985, pág. 30).

Existe otra forma de actuación del capital que desempeñó un papel fundamental en la producción de este bien y cuya figura social son los promotores. Su representante dijo que sEDUE debía garantizar la representatividad de todos aquellos que promueven la vivienda: contratistas, arquitectos, ingenieros, banca, abogados, notarios, publicistas, aseguradoras, financieros, afianzadores... y que:

"el sector privado intensifique su participación en las viviendas de interés social, ya que con su experiencia ha demostrado en el uso de la banca,

22 Dejamos por ahora de lado las caracteristicas que presenta la produccion de vivienda realizada a través de la autoconstrucción o autogestión de los usuarios, cuestión que trataremos al considerar la opción puesta en marcha para la reconstrucción de las vecindades céntricas. 
su capacidad de producir, de la calidad de su edificación, nulos o prácticamente nulos han sido y fueron los efectos del sismo en viviendas de interés social, de otra parte, el sujeto de crédito debidametne seleccionado por el promotor y cuidadosamente evaluado por la banca ha permitido la recuperación en todos los programas de vivienda".

Finalmente sostuvo:

"Ante la falta de una representatividad en el medio oficial, los promotores de vivienda en toda la República se encuentran mal agrupados en diversas cámaras, viéndose obligados a crear asociaciones para poder hacerse oír y para participar con la autoridad, por lo que me permito proponerle que se constituya la Cámara de la Vivienda, para que en esta actitud de renovación se puedan obtener los mejores resultados, para el pueblo mexicano" (Comisión Nacional de Reconstrucción, octubre, 1985, pág. 47).

Ciertamente las posibilidades de intensificar la actividad constructora en una coyuntura de crisis económica se incrementaron con el sismo. Sin embargo, lo que se desprende de esta posición empresarial es que la participación de tantos agentes económicos disputando la obtención de ganancias en la producción y comercialización de este bien indispensable, se traduce necesariamente en un encarecimiento del mismo. En este sentido, la política de vivienda puesta en marcha en los años setenta no logró contrarrestar estas formas de actuación del capital privado, al asumir el Estado una función principalmente financiera y de administrador de los intereses de los trabajadores del movimiento sindical organizado.

Los intelectuales, profesionales, técnicos y empresarios convocados a participar en estos órganos también acudieron; en sus intervenciones enfatizaron la importancia que presentaba el Decreto de expropiación de predios en las vecindades céntricas y reafirmaron su confianza en instaurar un proceso que beneficie a los sectores populares damnificados por el terremoto. ${ }^{23}$ Sin embargo, no siempre estuvo clara la forma de hacer efectiva la participación en estas comisiones. En contrapartida era evidente que la burocracia buscaba fuentes de consenso social y que los órganos de consulta cumplían ese objetivo.

Incluir a técnicos, profesionales y académicos dedicados a la cuestión de la vivienda de interés social implicaba que el personal del Estado estaba dispuesto a inaugurar nuevas formas de relación con estos sectores de la sociedad civil. La gestión urbana en sus diferentes niveles - planeación, acción institucional, acción política, asignación de recursos, realización de obras- no se ha caracterizado por ser un espacio de participación efectiva de representantes de los intereses de la ciudadanía en la resolución de sus problemas más cotidianos. En este sentido, el terremoto movilizaba rígidas estructuras burocráticas que inmediatamente percibieron que, en

23 Cfr. Comisión Nacional de Reconstrucción, Instalación de la Coordinación de Vivienda, octubre de 1985. 
un clima de solidaridad social generalizado, no podían aventurarse propuestas y soluciones surgidas exclusivamente de altos niveles dirigentes. El problema no era únicamente técnico-administrativo, sino que en un sentido amplio era político.

Esta actitud de quehacer burocrático abierta a los planteamientos externos se correspondió con la intención de presentar un manejo transparente en el uso de los fondos recibidos y administrados, tanto los del Fondo Nacional de Reconstrucción como la ayuda material recibida del extranjero. Se trataba entonces de generar confianza y ésta se transformó en sí en una meta, a la cual se dedicaron importantes esfuerzos. Los fondos recibidos por donaciones nacionales y extranjeras se destinaron exclusivamente a la reconstrucción de los establecimientos de salud y educativos, mientras que los fondos para la reconstrucción de viviendas provinieron de otras fuentes. ${ }^{24}$

Existieron también otras comisiones, las que desde su formación evidenciaban perseguir un objetivo político. La reconstrucción debía fundarse en la unidad: inmediatamente después de ocurrido el terremoto, el presidente creó la Comisión Metropolitana de Emergencia, en reunión de gabinete. También en el seno del Congreso de la Unión se instaló, 30 horas después de los sismos, una Comisión Especial Pluripartidista con el objetivo de proponer que se elaborase un plan de vivienda para los miles de damnificados, la suspensión de los juicios inquilinarios y de desalojos de viviendas populares y la reunión de los elementos legales y los estudios técnicos necesarios para entrar de inmediato a una discusión del más amplio espectro popular sobre la reforma urbana integral. ${ }^{25}$

El 11 de octubre se dio a conocer un acuerdo por el cual se creaba la Comisión de Reconstrucción del Distrito Federal. Al crearse la Comisión Nacional de Reconstrucción constituida por seis comités; aquélla fue transformada en el comité "encargado de integrar un programa de reconstrucción de la ciudad que conjugue las acciones públicas y privadas, para beneficio de todos los núcleos de población afectados por los sismos... (art. $1^{9}$ del acuerdo del 11/D.O.). Participaban tanto el presidente de la República quien lo presidiría, como el jefe del DDF actuando como coordinador así como servidores públicos cuyas atribuciones estuviesen relacionadas con los asuntos que se tratasen en el comité. También se invitaba a participar a personalidades "destacadas de la sociedad", así como a un representante, del Congreso del Trabajo, de la Confederación Nacional Campesina, de las organizaciones empresariales, de la UNAM, del Consejo Consultivo de la Ciudad de México, de la Unión Mexicana

24 El 17 de diciembre de 1985 se publicó un resumen sobre el destino del Fondo Nacional de Reconstrucción. Según dicho informe se contaba con $25 \mathrm{mil} 328$ millones de pesos y 8 millones de dólares, de los cuales se habían obtenido 1 mil 107 millo nes de pesos y 56 mil dólares por concepto de intereses y se habian destinado 6 mil millones a reparar escuelas y hospitales.

25 Cfr. Metrópoli del 26 de septiembre de 1985. 
de Asociaciones de Ingenieros y un representante del Colegio Nacional, quienes integrarían el pleno del comité. En su seno, conjuntamente con otros 9 más, funcionaría un subcomité de vivienda y habitación popular. En su instalación se hallaban presentes 5 ex jefes del DDF; uno de ellos expresó:

"que todos los mexicanos incluyendo los anteriores presidentes deben participar y consolidarse sin distinción alguna, y no quiere decir que requieran de una invitación especial o con trasfondo político... esto no es la reunificación de diversas fucrzas políticas provenientes del NRI, simplemente es una demostración de solidaridad con el pueblo y con el presidente" (Excélsior, 12 de octubre de 1985).

Sin embargo, mientras que las organizaciones del partido gobernante -inclusive aquellas que carecen de representatividad en el medio urbano por ser precisamente organizaciones rurales - formaron parte del pleno, no sucedió lo mismo con los representantes de los damnificados. En este caso, reeditando las formas de relación que se han establecido entre las instituciones del Estado dedicadas al problema habitacional y los usuarios, los canales institucionales son otros. La presencia de algún damnificado en estas reuniones no era suficiente para garantizar los objetivos gubernamentales; por ello, se crearon otras instancias, espacios de negociación, donde se dirimieron las demandas de los que habían perdido sus viviendas. En este caso, la eficacia de la gestión institucional en el ofrecimiento de alternativas habitacionales fue considerada la clave para generar - sin lograrla plenamente (véase Massolo, 1986 y Marván, 1986) la aceptación de la acción pública. El Programa Emergente de Vivienda que coordina SEDUE se dirigió a atender las necesidades habitacionales de los sectores medios, mientras que el Programa de Reconstrucción Habitacional Popular se ocupa de las construcciones de las vecindades céntricas.

\section{b) El Programa Emergente de Vivienda}

La SEDUE, al igual que la SAHOP en el sexenio anterior, posee atribuciones legales para ejercer funciones de coordinación de la acción pública habitacional en materia de vivienda. ${ }^{26}$ Sin embargo, las instituciones de vivienda que poseen una existencia anterior a la creación del organismo federal encargado de la planeación ejercen una acción autónoma, fijan sus metas, asignan sus recursos, delimitan su universo de atención y establecen sus propias modalidades de asignación de las viviendas.

El terremoto creó una nueva situación frente a la cual el Estado debía dar una respuesta rápicla y eficiente al problema habitacional. Días después del primer sismo, sedue en coordinación con el Departamento del DF elaboró lineamientos generales sobre un Programa Emergente de

26 Ley Federal de Vivienda, Diario Oficial de la Federación del 7 de febrero de 1984 . 
Vivienda para damnificados, convocando a los organismos financieros y operativos de vivienda a fin de ejecutar una acción coordinada en el marco de la Comisión Metropolitana de Emergencia. En principio era posible ofrecer a los damnificados de ingresos medios una rápida atención. basada en la adjudicación de la vivienda terminada que poseían diferentes organismos (INFONAVIT y Fovissste principalmente) y créditos para la adquisición de unidades existentes en el mercado privado. Los principales obstáculos que existían para efectuar esta acción estatal eran: 1) los organismos de vivienda adjudicarían vivienda a trabajadores asalariados "acreditados" ante los fondos como damnificados, 2) se trataba de una oferta limitada cuantitativamente en relación con las necesidades generadas. ${ }^{27} \mathrm{La}$ situación implicó un reacomodo en los procedimientos burocráticos y en las relaciones políticas que se estructuran alrededor de las instituciones de vivienda. Sin embargo, la situación demandaba la ampliación de alternativas habitacionales para el otro gran conjunto social afectado: los trabajadores urbanos no asalariados de muy bajo ingreso. Para estos últimos sólo PONHAPO contemplaba entre sus programas líneas de crédito de apoyo a la autoconstrucción o mejoramiento de vivienda popular. Sin embargo, la responsabilidad de este organismo en la administración de Tlatelolco, a través de AISA, llevó a que se creara una nueva Institución Renovación Habitacional Popular; en la creencia de que así se estaba en mejores condiciones de ejercer una acción con los sectores damnificados. Una evaluación muy próxima a la realidad indicaba que los albergues y los campamentos eran fuentes potenciales de conflicto social. ${ }^{28}$ Era una alternativa transitoria y precaria y se requería ofrecer inmediatamente la certeza de que el Estado comenzaría a aportar la ayuda prometida para reconstruir las vecindades. El decreto de expropiación de miles de vecindades constituyó la primera demostración del compromiso que asumía el gobierno con los sectores populares. El Programa Emergente de Vivienda respondía así a la demanda de dos grupos de familias:

1) Los residentes de los conjuntos habitacionales administrados por el Estado (Nonoalco-Tlatelolco y el Multifamiliar Benito Juárez).

2) Los residentes de condominios del sector privado que habían perdido viviendas que habitaban en calidad de inquilinos o propietarios.

La SEDUE asumió entonces la coordinación de esta acción organizando la oferta que el sector público podría presentar para esta población. Para ello estableció cuatro centros de atención: los módulos San Borja. Juan Cuamatzin, Crisantemos y Parque México, situados en lugares estratégicos

27 Los periódicos informaron sobre la limitada oferta disponible de los fondos habitacionales y la opinión vertida por las organizaciones sindicales que participan en la asignación de las mismas. Cfr. Excélsior, 25 de septiembre de 1985. Unomásunc. del 21 de diciembre de 1985.

28 Las dificultades para vivir en los campamentos y albergues se presentaron desde un inicio y perduraron hasta muchos meses después. Véase Unomásuno del 7 y 26 de diciembre de 1985. Proceso, núm. 470 del 4 de noviembre de 1985. 
de las zonas habitadas por capas medias más dañadas de la ciudad. Por otra parte, concentró la oferta habitacional de que disponían los organismos de vivienda estableciendo la disponibilidad de unidades, las restricciones que fijaban dichos organismos para la adjudicación y los requisitos exigidos a los destinatarios de la acción gubernamental. Es decir, asumió un carácter de organismo coordinador nunca antes ensayado.

Pero no sólo se trataba de iniciar una gestión intraburocrática, sino que sEDUE se transformó en el principal interlocutor de las organizaciones sociales que constituyeron los damnificados. Particularmente, estableció una relación de negociación directa con los representantes de Tlatelolco y el Multifamiliar Juárez, frente a los cuales aparecía el gobierno como administrador de sus viviendas. La inexistencia de una experiencia anterior de relación directa con las organizaciones de usuarios era la contrapartida de una gestión urbana tecnocrática y autoritaria. ${ }^{29}$ Para los residentes de condominios del sector privado la situación se presentó aún más difícil. Estas familias de inquilinos o de propietarios -que en muchos casos habían adquirido su vivienda sacrificando otros consumos esenciales- continúan reclamando una respuesta de las instituciones estatales que les permita acceder a una vivienda definitiva $\mathrm{y}$ acorde a sus demandas. ${ }^{30}$

El 20 de enero de 1985 la sedue había registrado 17713 cédulas de familias de damnificados conteniendo los principales datos sobre la composición familiar y las necesidades de vivienda generadas por el terremoto (cuadro núm. 16). De las mismas, 14083 fueron canalizadas, es decir, se remitieron a diferentes organismos de vivienda con la finalidad de hallar una alternativa habitacional acorde con sus posibilidades y necesidades. En esa fecha se habían asignado ya 5208 viviendas y 4628 créditos, es decir, prácticamente un 70 por ciento de las solicitudes se hallaban en camino de encontrar una respuesta (cuadro núm. 16).

Es importante señalar que en un alto porcentaje, las demandas de los damnificados de los sectores medios fueron satisfechas a través de las opciones que ofrecieron los organismos de vivienda. Consideradas las solicitudes globalmente, el INFONAvit atendió el 31.72 por ciento y el Fovissste el 36.15 por ciento. Para quienes no existía esa posibilidad se abrieron créditos de Fovi-BANCA a los que accedieron el $14.37 \%$ de los solicitantes, AURIS en el estado de México atendió un $10.57 \%$ y PEMEx a un $6.32 \%$, familias de trabajadores pertenecientes a la empresa. Fovissste atendió a prácticamente la totalidad de los damnificados del Multifamiliar Juárez, $y$ al $28.29 \%$ de los damnificados de Tlatelolco. INFonavit atendió al $19.38 \%$ de Tlatelolco mientras que Fovi-BANCA ofreció un 34.41 por cien-

29 Véase entre otras: Unomásuno del 22 de noviembre de 1985. El Día del 28 de septiembre de 1985 y Proceso, núms. 470 y 471 del 4 y 11 de noviembre de 1985. Cfr. A. Massolo (1986) e I. Marván (1986).

so Cf. Fxcelsior, 6 de febrero de 1986. 
to, PEMEX un $11.25 \%$ y Fovimi-ISSSFAM un 5.01 por ciento a estas familias (véase cuadro núm. 16).

De todas formas, interesa señalar que infonavir dispuso en total de 2347 viviendas, siendo que tenía programada para 1985 la construcción de 72748 unidades habitacionales. De igual forma, rovissste asignó 1541 viviendas de 15272 programadas para ese año y 4234 de 6435 créditos que planeaba entregar. Fovi-BANGA asignó 661 viviendas de 82277 programadas. Es decir, la adjudicación de vivienda y créditos a los damnificados pudo ser enfrentada por los organismos de vivienda sin que ello alterara sustancialmente sus programas de acción anual (cuadros núms. 17 y 18 ).

La población atendida por la SEDUE era predominantemente de inquilinos, quienes pudieron obtener una opción habitacional en propiedad a partir de su condición de damnificados. Los problemas se suscitaron más bien por la localización de la oferta estatal en los municipios del estado de México, puesto que se trataba de una población que residía, desde muchos años atrás, y por varias generaciones en una localización central. Las condiciones que presentan los servicios y el equipamiento habitacionales constituyeron otro obstáculo para garantizar que efectivamente esta población logrará resolver definitivamente su problema habitacional.

Otro hecho importante es que los precios de las viviendas ofrecidas eran muy bajos para hacerlos accesibles a un número mayor de demandantes; esto es consecuencia de que se ha exentado a los compradores del pago de impuestos por concepto de adquisición y de derecho del registro que fija la Ley de Hacienda del DF al igual que las condonaciones autorizadas por el gobierno del estado de México. Esta reducción de cargas fiscales se suma al hecho de que los notarios de la zMGM no cobraron sus gastos de escrituración "lo que disminuye en un $15 \%$ el valor comercial de las viviendas". ${ }^{31}$ Sin embargo, el hecho de que se haya canalizado un alto porcentaje de cédulas, no asegura que se haya resuelto el problema habitacional de estas familias: el derecho a una vivienda o un crédito supone, aun en tiempos normales, recorrer el camino de cumplir con una serie de requisitos burocráticos y administrativos. Al mismo tiempo, la posibilidad de concretar la atención gubernamental depende en gran medida de que la oferta sea acorde a las expectativas de los demandantes.

En Tlatelolco, el 53 por ciento de las solicitudes aceptaron una respuesta gubernamental ya sea en viviendas o créditos. Según la sedue (1986) quedan por liquidar 600 departamentos de los 3812 que fueron declarados inhabitables y en los que sus habitantes están decididos a mantener su arraigo (cuadro núm. 19).

Las negociaciones que emprendieron sus habitantes a través de sus organizaciones sociales impusieron condiciones a las alternativas of recidas por sEdue. Durante muchos años se fueron generando problemas en re-

31 SEDUE, Informe del 21 de enero de 1986. 
CUADRO 16

PROGRAMA EMERGENTE DE VIVIENDA

REPORTE GLOBAL ACUMULADO HASTA EL 20 DE ENERO DE 1986

Asignación por centro de atención

\begin{tabular}{|c|c|c|c|c|c|c|c|}
\hline $\begin{array}{l}\text { Centros } \\
\text { de atención }\end{array}$ & $\begin{array}{l}\text { Cédulas } \\
\text { registradas }\end{array}$ & $\begin{array}{l}\text { Cédulas } \\
\text { canalizadas }\end{array}$ & $\begin{array}{l}\text { Cédulase } \\
s \text { proceso }\end{array}$ & $\begin{array}{l}\text { en Cédulas } \\
\text { rechazadias }\end{array}$ & $\begin{array}{l}\text { Viviendas } \\
\text { asignadas }\end{array}$ & $\begin{array}{c}\text { Créditos } \\
\text { asignados }\end{array}$ & Total \\
\hline Sar & & 3 & 28 & 43 & 1 & & 2287 \\
\hline matzin & n 55 & 45 & 20 & 86 & 5 & 10 & 254 \\
\hline Crisanten & 56 & 45 & 20 & 83 & 1401 & 79 & 21 \\
\hline Parque México & & 14 & 47 & 16 & 928 & 293 & 1221 \\
\hline Total & 17713 & $14236^{1}$ & 1170 & 2307 & 5039 & 3201 & 8240 \\
\hline
\end{tabular}

Asignación por tipo de población

Unidad Cédulas Cédulas Cédulas en Cédulas Viviendas Créditos

habitacional registradas canalizadas proceso rechazadas asignadas asignados Total

\begin{tabular}{|c|c|c|c|c|c|c|c|}
\hline \multicolumn{8}{|l|}{ Nonoalco- } \\
\hline $\begin{array}{l}\text { Tlatelolco } \\
\text { Presidente }\end{array}$ & 4299 & 4103 & 135 & 61 & 1125 & 1059 & 2184 \\
\hline $\begin{array}{l}\text { Benito Juárez } \\
\text { Población }\end{array}$ & 728 & 676 & 40 & 12 & 338 & 248 & 586 \\
\hline abierta & 12686 & 9457 & 995 & 2234 & 3576 & 1894 & 5470 \\
\hline Total & 17713 & $14236^{1}$ & 1170 & 2307 & 5039 & 3201 & 8240 \\
\hline \multicolumn{8}{|c|}{ Asignación por organismo } \\
\hline Organismo & \multicolumn{2}{|c|}{$\begin{array}{c}\text { Cédulas } \\
\text { canalizadas }\end{array}$} & \multicolumn{2}{|c|}{$\begin{array}{l}\text { Viviendas } \\
\text { asignadas }\end{array}$} & \multicolumn{2}{|c|}{$\begin{array}{l}\text { Créditos } \\
\text { asignados }\end{array}$} & Total \\
\hline Fovissste & \multicolumn{2}{|c|}{5747} & \multicolumn{2}{|c|}{1541} & \multicolumn{2}{|c|}{$4234^{2}$} & 5775 \\
\hline Infonavit & \multirow{2}{*}{\multicolumn{2}{|c|}{$\begin{array}{l}4072 \\
2229\end{array}$}} & \multicolumn{2}{|c|}{2347} & \multicolumn{2}{|c|}{332} & 2679 \\
\hline Fovi/Banca & & & \multirow{2}{*}{\multicolumn{2}{|c|}{$\begin{array}{l}661 \\
490\end{array}$}} & \multicolumn{2}{|c|}{ - } & 661 \\
\hline Auris & \multicolumn{2}{|c|}{1623} & & & \multirow{2}{*}{\multicolumn{2}{|c|}{$\overline{50}$}} & 490 \\
\hline Pémex & \multicolumn{2}{|c|}{339} & \multicolumn{2}{|c|}{$\begin{array}{l}490 \\
145\end{array}$} & \multirow{2}{*}{\multicolumn{2}{|c|}{12}} & 195 \\
\hline GFE & \multirow{2}{*}{\multicolumn{2}{|c|}{$\begin{array}{l}40 \\
30\end{array}$}} & \multicolumn{2}{|r|}{24} & & & 36 \\
\hline Isssfam-Fovimi & & & \multicolumn{2}{|r|}{ 一 } & \multicolumn{2}{|c|}{ - } & - \\
\hline Total & \multicolumn{2}{|c|}{14083} & \multicolumn{2}{|c|}{5208} & \multicolumn{2}{|l|}{4628} & 9836 \\
\hline
\end{tabular}




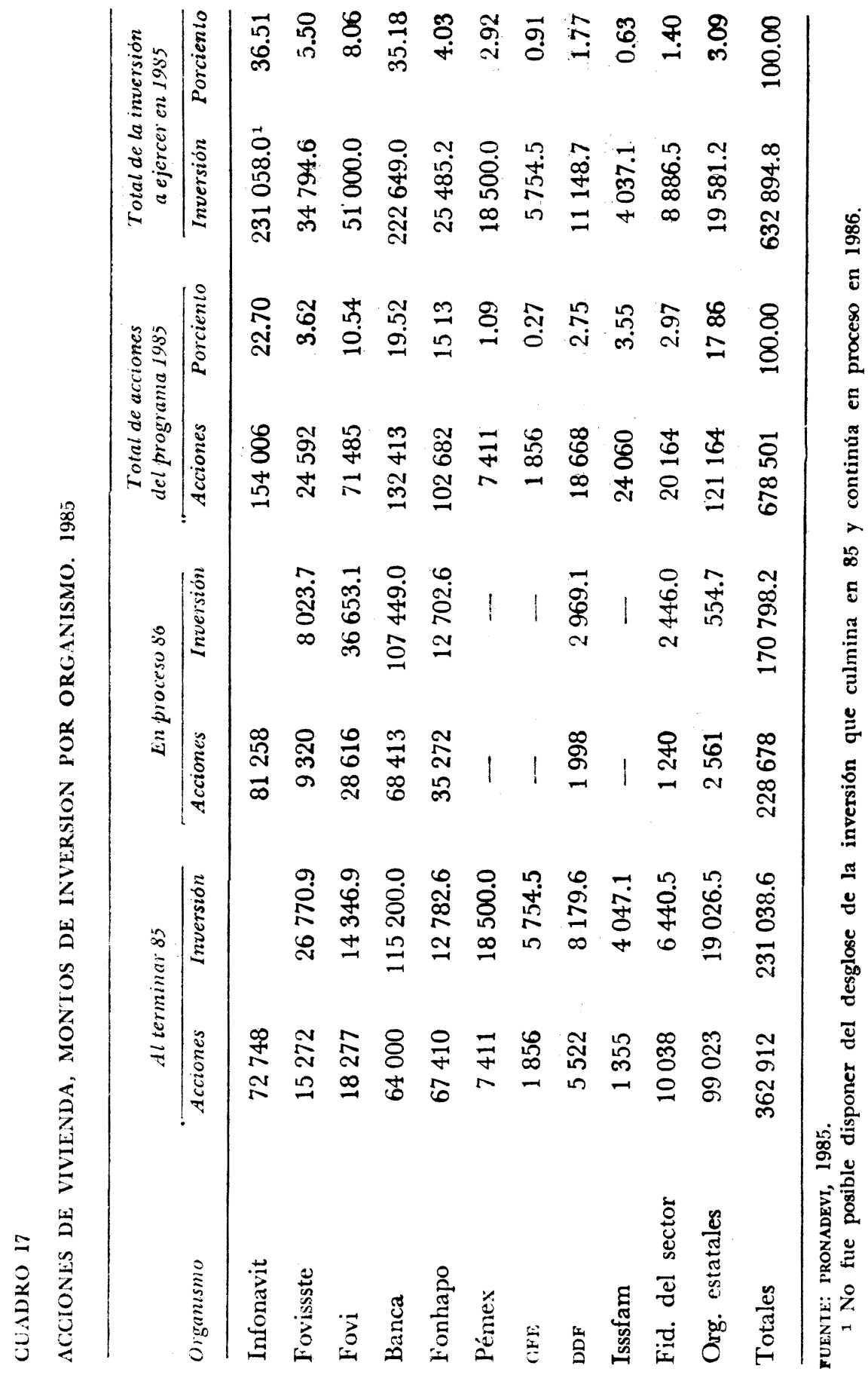




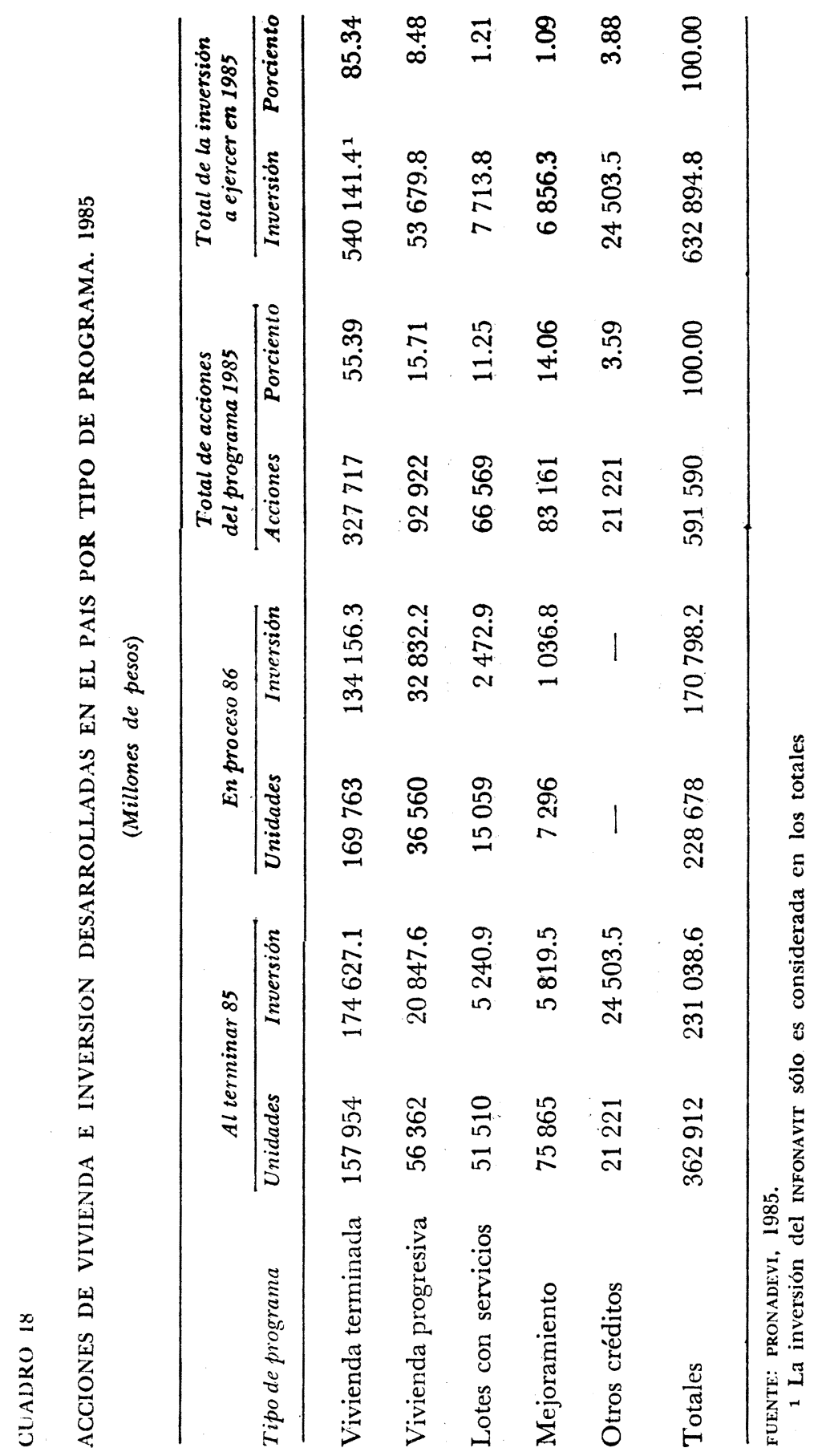


POLÍTICA DE: VIVIENDA

CUADRO 19

SITUACION ACTUAL DE LOS EDII ICIOS DE TLATELOLCO

\begin{tabular}{cll}
\hline Número & \multicolumn{1}{c}{ Situación actual } & \multicolumn{1}{c}{ Destino } \\
\hline 20 & $\begin{array}{l}\text { Gravemente dañados en } \\
\text { sus estructuras }\end{array}$ & $\begin{array}{l}\text { Clausura y declaratoria } \\
\text { de destino final }\end{array}$ \\
7 & $\begin{array}{l}\text { Daños regulares en sus } \\
\text { estructuras }\end{array}$ & $\begin{array}{l}\text { Factible su reparación y } \\
\text { reconstrucción }\end{array}$ \\
11 & $\begin{array}{l}\text { Daños de importancia sin } \\
\text { afectar su estructura } \\
\text { Reparación sin necesidad } \\
\text { Daños menores sin riesgo } \\
\text { para sus habitantes }\end{array}$ & $\begin{array}{l}\text { Rehabilitación } \\
\text { Re }\end{array}$ \\
& &
\end{tabular}

FENTE: sedue, Informe a la Comisión Especial Pluripartidista del Congreso de la Unión, 21 de enero de 1986.

lación con la forma de tenencia de los departamentos y a la falta de mantenimiento adecuado. El cambio de uso de muchas viviendas, instalación de bodegas, depósitos y cuartos de azotea, generaron una composición social heterogénea, para la cual la respuesta del gobierno fue diferenciada en función de sus características sociales y derechos adquiridos.

La SEDUE organizó la realización de trabajos técnicos en los 84 edificios administrados por FONHAPO-AISA; otorgó un pago diario por mantenimiento (4000 pesos) a las familias del Nuevo León y acordó ofrecer alternativas habitacionales con los habitantes de 27 edificios que resultaron gravemente dañados. Sin embargo, como se dijo, un elevado número de familias expresan su deseo de permanecer en Tlatelolco.

La población del Multifamiliar Juárez, numéricamente más pequeña, encontró opciones en un $86 \%$. Allí se encontró una alternativa habitacional para un elevado número de familias. Según sedue, quedan 90 casos sin resolver debido a que demandan mejores opciones habitacionales que las ofrecidas.

Para los sectores medios que habitaban condominios del mercado privado, subsisten problemas porque no pueden acceder fácilmente a una vivienda de la calidad de la que tenían. La lejanía de la oferta del sector público y las condiciones precarias del medio en que se localizan las viviendas del sector público, así como el bajo monto de los créditos de interés social para optar por una unidad del mercado privado, limita sus posibilidades. De igual forma, para los sectores de más bajos ingresos, habitantes en azoteas, jubilados y pensionados, una población no asalariada, hacer frente al pago de una cuota, aun cuando ésta sea baja, es muy difícil. 
CUADRO 20

TOTAL DE PREDIOS EXPROPIADOS

Delegación: ,cuAuHTÉmoc

\begin{tabular}{lrlrr}
\hline Colonia & Núm. & & Colonia & Núm. \\
\cline { 1 - 1 } Algarín & 11 & & Guerrero & 358 \\
Ampliación Asturias & 12 & & Maza & 18 \\
Asturias & 2 & Morelos & 325 \\
Atlampa & 70 & & Obrera & 410 \\
Buenavista & 131 & Paulino Navarro & 20 \\
Buenos Aires & 35 & Peralvillo & 188 \\
Centro & 473 & San Simón Tolnáhuac & 84 \\
Doctores & 297 & Tránsito & 43 \\
Esperanza & 14 & Valle Gómez & 54 \\
Ex-Hipódromo de Peralvillo & 42 & Vista Alegre & 15 \\
Felipe Pescador & 4 & &
\end{tabular}

Delegación: Gustavo A. MADERo

\begin{tabular}{lrrrr}
\hline Colomia & Núm. & & Colonia & Núm. \\
\cline { 1 - 1 } 2a. Sección Gertrudis Sánchez & 6 & & La Joyita & 4 \\
7 de Noviembre & 2 & & Malinche & 17 \\
Aragón-Inguarán & 6 & & Mártires de Río Blanco & 12 \\
Bonciojito & 9 & Martín Carrera & 1 \\
Casas Alemán & 1 & Peralvillo & 2 \\
Emiliano Zapata & 1 & Río Blanco & 11 \\
Faja de Oro & 2 & Sirte de Noviembre & 37 \\
Fernando Casas Alemán & 1 & Tablas de San Agustín & 16 \\
Gertrudis Sánchez & 33 & Vallejo & 43 \\
Héroes de Nacozari & 9 & & \\
La Joya & 14 & &
\end{tabular}


POLÍTICA DE VIVIENDA

CUADRO 20. CONTINUACIÓN:

TOTAL DE PREDIOS EXPROPIADOS

Delegación: venustiano carRanza

\begin{tabular}{lrrlr}
\hline Colonia & Núm. & & Colonia & Núm. \\
\cline { 1 - 1 } 10 de Mayo & 20 & & Cuchilla Pantitlán & 15 \\
20 de Noviembre & 10 & & Damián Carmona & 11 \\
Aeronáutica Militar & 2 & & Emilio Carranza & 91 \\
Aarón Saenz & 5 & Federal & 19 \\
Álvaro Obregón & 12 & Felipe Angeles & 10 \\
Ampliación 20 de Noviembre & 10 & Ignacio Zaragoza & 17 \\
Ampliación Michoacán & 3 & Jamaica & 10 \\
Ampliación Penitenciaría & 19 & Janitzio & 19 \\
Artes Gráficas & 18 & Lorenzo Boturini & 9 \\
Aviación Civil & 12 & Magdalena Mixhuca & 16 \\
Azteca & 12 & Merced Balbuena & 61 \\
Caracol & 6 & Moctezuma & 15 \\
Centro & 267 & Morelos & 412 \\
Cuatro Árboles & 7 & Nicolás Bravo & 24
\end{tabular}

Delegación: gustavo A. MADERo

\begin{tabular}{|c|c|c|c|}
\hline Colonia & Núm. & Colonia & Núm. \\
\hline Penitenciaría & 30 & Sevilla & 7 \\
\hline Popular Rastro & 20 & Siete de Julio & 3 \\
\hline Puebla & 11 & Sta. Cruz Aviación & 1 \\
\hline Pueblo Magdalena Mixhuca & 32 & Venustiano Carranza & 21 \\
\hline Quinto Tramo de 20 de Nov. & 38 & Valentín Gómez Farías & 20 \\
\hline Romero Rubio & 15 & Valle Gómez & 137 \\
\hline
\end{tabular}




\section{c) El Programa de Renovación Habitacional Popular}

\section{- La expropiación de predios}

Los terremotos vinieron a agudizar la situación de deterioro habitacional que existía en varias colonias del centro de la ciudad. Las viejas vecindades, al ser destruidas total o parcialmente, dejaron de ser el albergue de un elevado número de familias. Las posibilidades de reparar estas viviendas encontraban una serie de obstáculos legales y sociales que los grupos de profesionales y técnicos que se acercaron inicial y solidariamente a prestar ayuda detectaron inmediatamente. Los obstáculos legales provenían de las múltiples formas de tenencia que las viviendas presentaban; en la mayoría de los casos se trataban de situaciones legalmente confusas: propietarios desinteresados en sus predios, herederos que no ejercían sus derechos, propiedades cuyos dueños fallecieron intestados. No menos importantes eran los conflictos sociales existentes surgidos de la actitud de muchos propietarios que no cumplían con las obligaciones legales de ofrecer mantenimiento a las viviendas argumentando que el bajo monto de las rentas no les permitía realizar tales mejoras; las amenazas de desalojo recurrentes para un considerable número de familias; la falta de estímulos entre los inquilinos para invertir parte de su bajo ingreso en un bien que no era de su propiedad. En este contexto, la decisión presidencial de expropiar más de tres mil vecindades debe interpretarse como una acción necesaria para llevar a cabo la reconstrucción de manera rápida y garantizar a esta población el derecho a la vivienda consagrado en la Constitución de la República.

El decreto expropiatorio fue publicado en el Diario Oficial el 11 de octubre de 1985 y la trascendental decisión gubernamental fue dada a conocer por el regente de la ciudad con motivo de la instalación de la Comisión de Reconstrucción del DF. La ausencia de un catastro actualizado llevó a que originariamente se incluyera un conjunto de predios que no respondía a la intención oficial de garantizar la vivienda a los sectores populares de menores ingresos del centro de la ciudad. La depuración que se llevó a cabo fue para excluir aquellos bienes que no estaban ubicados en colonias populares (como fue el caso de las viviendas de la delegación Benito Juárez, originariamente incorporadas en el decreto), corregir errores derivados de numeración oficial equivocada y excluir viviendas unifamiliares o que ya hubiesen sido adquiridas por los vecinos aún cuando legalmente no estuviese registrada esta transacción. Todo cllo llevó a que el número inicial de 7000 predios se redujera prácticamente a 3000 , los que pasaron a formar la lista de un segundo decreto dado a conocer el 21 de octubre. Pero los errores iniciales en el listado evidencian ciertamente algunos de los difíciles problemas que se generan en torno a la vivienda de los sectores populares; sobre todo, ponen de manifiesto las dificultades administrativas, políticas, económicas y burocrá- 
ticas que deben sortearse aun cuando se pretenda hallar una resolución. Según Renovación Habitacional Popular, el decreto expropiatorio incluyó finalmente 4332 predios, en los que se localizan 3911 vecindades habitadas por 44788 familias y localizadas en las tres delegaciones centrales: Cuauhtémoc, Venustiano Carranza y Gustavo A. Madero (cuadro núm. 18). ${ }^{32}$

Los fundamentos gubernamentales que acompañaron a la medida fueron de amplio y diverso orden, siendo los de mayor importancia social los referidos a que: 1) las colonias populares del centro de la ciudad son áreas que el tiempo y el abandono han convertido en un hábitat degradado y con graves problemas sociales, 2) los programas de rehabilitación instrumentados anteriormente habían dado resultados parciales que no corresponden a la magnitud de los problemas, 3) esta situación fue agravada por el deterioro de miles de viviendas, cuyos habitantes ante el derrumbe o el riesgo, debieron abandonar sus casas y vivir en la calle, 4) la mayoría de las viviendas estaban sujetas al régimen de arrendamiento, en muchos casos en "rentas congeladas" establecidas por las disposiciones de 1942 o porque las condiciones de habitabilidad que ofrecían no permitían al propietario incrementar el monto del alquiler. $\mathrm{Ni}$ propietarios ni inquilinos tenían motivaciones personales para mejorar la calidad de vida: unos porque no recibían un ingreso suficiente por la renta, los otros porque no tenían estímulos para invertir sus escasos ahorros en mejorar una vivienda que no era de su propiedad, 5) la población que habitaba en las vecindades eran miembros de familias con muchas décadas de arraigo en la zona, con una gran identificación con su barrio en que llevan a cabo prácticamente la totalidad de sus actividades. Peralvillo, Tepito, Morelos, Guerrero eran barrios cuya regeneración formaba parte de la necesidad de preservar la fisonomía y las tradiciones que se conformaron desde el México Colonial. ${ }^{33}$

El DDF inmediatamente comenzó a ejecutar la medida constituyendo brigadas para revisar los inmuebles expropiados, censar a sus habitantes e instalar un cartel en su puerta con la leyenda: "Este inmueble es propiedad del DDF y será destinado al Programa de Vivienda ordenado por el C. Presidente de la República". La medida contó con la aprobación de las fuerzas sociales representativas de los intereses populares, recrudeció la desconfianza de algunos sectores del capital y la reprobación de agrupaciones defensoras de propietarios de inmuebles de la ciudad. Los vecinos del centro de la ciudad, particularmente los habitantes del barrio de Tepito, que habían reivindieado desde antes la expropiación y las familias beneficiadas con la medida organizaron una manifestación a la

32 Renovación Habitacional Popular. Informe de Actividades del 15 de enero de 1986 .

33 Comisión Nacional de Construcción. Informe del 19 de septiembre al 19 de octubre de 1985. pp. 11 y 12. 
casa presidencial para respaldar la decisión gubernamental y solicitar que la expropiación se ampliase a un número mayor de predios a fin de garantizar plenamente la reconstrucción. ${ }^{34}$ Las organizaciones del partido gobernante, así como los representantes de los partidos políticos de oposición defensores de los intereses populares (PSUM, PST), manifestaron su apoyo a la medida gubernamental.95 En contraposición, la concanaco calificó el decreto de "regresivo y populista y paternalista" 38 y la Barra Mexicana, Colegio de Abogados, manifestó que los decretos expropiatorios son inconstitucionales porque no cumplen con dos requisitos que el artículo 27 constitucional exige para realizarla: 1) que exista causa de utilidad pública y 2) que la expropiación se haga mediante indemnización. ${ }^{37}$

En realidad no existía otra opción institucional capaz de garantizar el derecho de los inquilinos a continuar habitando el centro. Existe consenso en que la congelación de rentas, como forma de frenar los incrementos de los alquileres, experiencia realizada en los años cuarenta en distintos países latinoamericanos, es la causa de: 1) la falta de inversión privada en vivienda, 2) el deterioro de las casas que se hallan bajo este régimen. Intentar una rehabilitación en la que los propietarios continuaran ejerciendo sus derechos sobre las viviendas y los inquilinos tuvieran garantizado su arraigo, condiciones de habitabilidad dignas y rentas acordes a sus ingresos, implicaba llevar a cabo una negociación individual entre propietario e inquilinos de cada predio y con bajas posibilidades de realizar un pacto exitoso en los términos expuestos y que fuese respetado con posterioridad. La expropiación, en cambio, constituyó un recurso constitucional que en el medio urbano fue aplicado de manera recurrente desde los años treinta, cuando comenzaba a expandirse el centro de la ciudad por la formación de colonias populares en su periferia (véase Ziccardi, 1982).

Sin embargo, el principal requisito para que esta decisión efectivamente despejase la intranquilidad social de las clases populares del centro era que la tenencia se transfiriese sin demoras, en propiedad a los actuales inquilinos. La experiencia indica que no son pocos los casos en que una expropiación en la ciudad de México origina nuevas situaciones jurídicas irregulares que se prolongan en el tiempo indefinidamente; tal es el caso de aquellos predios afectados por una expropiación bajo el fundamento de "utilidad pública" en los que sus propietarios se amparan y logran que proceda su reclamo. De igual forma, los cambios de autoridades gubernamentales - principalmente en los cambios sexenales- pueden lle-

34 El 3 de octubre, Excélsior publicaba un artículo titulado: "Pidieron los dam nificados de Tepito la expropiación de las casas dañadas".

ss Cfr. Excélsior del 14 de octubre de 1985.

36 Cfr. Excélsior del 15 de octubre de 1985.

37 Cfr. Excelsior del 20 de diciembre de 1985. 
var a que las decisiones no se concreten en una situación legal clara aun cuando los destinatarios de la acción se hubieren beneficiado (véase Azuela y Cruz, 1984). No se conoce con precisión cuál ha sido la respuesta de los propietarios de los predios afectados. Informaciones periodísticas indicaron que el regente de la ciudad había ordenado la revocación de 125 predios aféctados originariamente. ${ }^{38}$ Posteriormente se informó que de 125 solicitudes de revocación, 46 se habían aprobado y 6 habían sido denegadas porque en esos casos la expropiación se ajustaba al espíritu del decreto. ${ }^{39}$ Pero más allá de los efectos de orden jurídico es imposible evaluar con certeza, en este momento, cuáles van a ser los efectos sociales que pueden derivarse de una medida gubernamental como ésta. Lo importante es que la misma sirvió para vencer el primer obstáculo que enfrentaba una reconstrucción que pretendía salvaguardar los intereses populares. Las modalidades que asuma la reconstrucción de las viviendas dañadas y el de producción de nuevos inmuebles en los predios baldíos expropiados, la capacidad que expresen las formas organizativas de los vecinos para garantizar sus derechos y el rumbo que se imprima a la participación gubernamental son elementos que estarán presentes en esta nueva etapa del proceso de apropiación y uso del suelo urbano.

\section{- La creación de Renovación Habitacional Popular}

\section{Caracteristicas del organismo}

Para dar cumplimiento a la intención de llevar a cabo un proceso de reconstrucción de las viviendas populares del centro de la ciudad que favoreciese a los habitantes de las mismas garantizando su arraigo, se decidió la creación de un nuevo organismo gubernamental denominado: Renovación Habitacional Popular. Las principales funciones asignadas a este organismo público descentralizado y con patrimonio propio son las siguientes (cuadro núm. 21):

Estas funciones asignadas le permiten al nuevo organismo poseer un amplio respaldo legal para ejecutar prácticamente cualquier acción institucional sobre el espacio urbano del DP. Por otra parte, en su cumplimiento puede actuar por su cuenta o por terceros, lo cual le permite abrir un abanico de relaciones con diferentes agentes económicos y sociales que participarán en este proceso de reconstrucción.

En cuanto a la forma de autoridad, Renovación Habitacional cuenta con un director general y una junta de gobierno constituida por representantes de diferentes secretarías de Estado y organismos financieros. Pero lo central es que esta institución fue creada para poner en marcha el primer

s8 Cfr. Unomásuno del 21 de noviembre de 1985.

29 Cfr. Unomásuno del 25 de noviembre de 1985. 
CUADRO 21

FUNCIONES DE RENOVACION HABITACIONAL POPULAR

1) Promover y ejecutar programas de vivienda y de fraccionamientos urbanos de interés social, para las clases populares urbanas de bajos ingresos.

2) Construir, reconstruir y conservar obras de infraestructura y equipamientos urbanos.

3) Adquirir, enajenar, urbanizar, permutar o construir sobre los inmuebles urbanos.

4) Gestionar, obtener, otorgar créditos, así como promover el establecimiento de sistemas de crédito para facilitar la adquisición de viviendas a los beneficiarios, considerando su capacidad de pago.

5) Establecer sistemas de apoyo técnico y financiero hacia los programas de autoconstrucción y regeneración de las viviendas afectadas, así como para el funcionamiento de cooperativas de vivienda de conformidad con el Programa.

6) Coadyuvar en la satisfacción de la demanda de suelo urbano, vivienda de interés social, infraestructura y equipamiento urbano de la Zona Metropolitana del Distrito Federal contribuyendo a regular el mercado de terrenos.

7) Propiciar la participación de la comunidad en la ejecución de las acciones, obras e inversiones que realicen, en especial de los grupos vecinales correspondientes.

8) Celebrar toda clase de Convenios y de Contratos para el cumplimiento de su objeto.

9) Las demás acciones que se requieran para la ejecución del Programa Emergente de Renovación Habitacional Popular del Distrito Federal.

Fuente: Decreto por el que se aprueba el Programa Emergente de Renovación Habitacional Popular del Distrito Federal. Diario Ofictal de la Federación, 14 de octubre de 1985.

programa de mejoramiento habitacional popular masivo que se efectúa en el país y en el contexto latinoamericano. Como es sabido, las soluciones ofrecidas por estos gobiernos para mejorar las condiciones de vida de las clases populares han coincidido, aun bajo los más diferentes regímenes 
políticos, en ofrecer su relocalización. Tanto la opción de los condominios como los programas de apoyo a la autoconstrucción consistieron en crear una periferia lejana en la cual habitaran las clases populares urbanas. Con ello se reforzó el patrón de urbanización periférico que protagonizan las clases populares al buscar un terreno de muy bajo precio en el cual autoconstruir una precaria vivienda. El desafío que enfrenta este programa, en cambio, es el garantizar a la población su derecho a continuar viviendo en el centro de la ciudad de México.

La amplitud de la tarea emprendida llevó a la formación de 13 jefaturas de Zona en la sque se distribuye la totalidad de los predios incluidos en el decreto expropiatorio y cuyas viviendas deberán ser reconstruidas. También se instalaron cuatro parques de materiales poniendo nuevamente a prueba un sistema de comercialización con participación gubernamental a fin de garantizar el acceso a los principales materiales de construcción y a precios más bajos que los que se ofrecen en el mercado. Pero en los primeros momentos de actuación de este organismo, la labor más intensa ha consistido en llevar a cabo la llamada "promoción social", que consiste en informar a la población para que se constituyan mesas directivas denominadas "Consejos de renovación" formas de representación de cada vecindad. La expedición de un certificado personal de derechos garantiza al jefe de familia la propiedad de una vivienda digna y decorosa, respetando la vecindad y el arraigo de los pobladores originales (véase Renovación Habitacional Popular, 1985).

Los recursos financieros con que contará el organismo han sido incluidos en el presupuesto de la federación, pero debe tenerse en cuenta que el Banco Interamericano de Reconstrucción y Fomento está negociando un importante crédito para ser destinado a la reconstrucción del centro de la ciudad, particularmente para vivienda popular. Según informaciones obtenidas, en una primera etapa el BIRF otorgó 150 millones de dólares, los cuales serán aplicados de acuerdo con las reglas de operación de FONHAPO, organismo propuesto como instrumento financiero del gobierno federal. ${ }^{40}$ La principal razón es que, neutralizados los conflictos políticos, este organismo cuenta con experiencia en la adjudicación de créditos a población no asalariada de bajos ingresos (menos de 2.5 v.s.m.) organizada en grupos de no menos de cien familias; en contrapartida, Renovación Habitacional Popular es una institución de vida efímera, puesto que fue plan-

40 En realidad no es la primera vez que organismos internacionales han aportado importantes recursos para llevar a cabo proyectos de desarrollo urbano. Entre los más recientes créditos pueden mencionarse los otorgados por el BIRF para agua potable y alcantarillado en el que el agente técnico es sebue. Además otorgó otro crédito a sFDue para llevar a cabo el Programa de Control de la Contaminación en México, y a la Comisión de Conurbación de la Zona Centro para el Programa de Desarrollo de la Zona Centro del País. El bID otorgó un crédito a los estados y mu. nicipios para la construcción del Fondo Fiduciario de Fomento Münicipal destinado a infraestructura básica en poblaciones de 2500 a 100000 habitantes. 


\title{
CUADRO 22
}

\section{ACCIONES DE RENOVACION HABITACIONAL POPULAR}

\author{
AL 15 DE ENERO DE 1986
}

Atención a vecindades en riesgo

- 879 vecindades de alto riesgo

- 100 mil piezas de madera distribuidas para apuntalamientos y vivienda provisional

- 15 mil láminas galvanizadas, así como herramienta y equipo para demoliciones

- 120 vecindades demolidas

$-82500 \mathrm{~m}^{3}$ de escombro retirado

Alojamientos provisionales a cargo de las delegaciones

- más de 1000 alojamientos habilitados por las delegaciones

- 141 campamentos en la vía pública que representan otras 2330 familias

-3887 familias que deben ser reacomodadas por desocupación con motivo de las obras

- 5209 alojamientos requeridos para cuero

- 500 alojamientos más a partir de febrero por obras

- renovación en la instalación de nuevos alojamientos

Organización comunitaria

- más de 7000 asambleas de orientación e información

- $3520(90 \%)$ consejos de renovación

- 100 convenios de obra con los beneficiarios

- diálogo con organizaciones y partidos políticos

Acreditación de derechos

- 31000 cédulas de identificación inicial

- más de 10000 cédulas socioeconómicas

- 17358 certificados de derechos elaborados

- 12000 certificados entregados

\section{Trabajos de evaluación técnica y proyectos}

- 4332 inspecciones realizadas

- 3911 dictámenes técnicos para determinar los trabajos de reconstrucción

- reparación menor 8587 viviendas

- rehabilitación 14940 viviendas

- reconstrucción 21261 viviendas

- viviendas en baldíos: 1944 viviendas; que podrian disminuir dado que algunos de estos predios serán usados para obras de intraestructura y equipamiento urbano.

- elaboración del programa general de reconstrucción, calendarizado trimestralmente durante 1986

- 863 proyectos para viviendas

- 27 proyectos de restauración en predios catalogados como sitios o monumentos históricos

Desarrollo de las obras

- 20 obras en proceso

- 510 vecindades y obras para iniciar a partır del 1 de enero

- 450 vecindades y obras para iniciar el 1 de febrero

- más de 180 frentes de trabajo para atacar por paquetes el proceso de reconstrucción

- estos trabajos son apoyados por proyectistas y empresas de ingeniería 
CUADRO 22

\section{AL. 15 DE ENERO DE 1986 (conimuación)}

Predios y zecindades susceptibles de compra

- planteamientos de compra a terceros de 1000 vecindades afectadas, siendo suscep. tibles de compra 100 con recursos vía fonHapo

Pririues de materiales

- 10 parques de materiales instalados

Adjudicación y escrituración

- presentación a la cámara de diputados de una iniciativa de ley que adiciona la ley del condominio, creaindo la modalidad del "Condominio vecinal populaR"

- preparación de documentación para escrituración

- enlace con la Comisión de Avalúos de Bienes Nacionales a lin de integrar el costo de la tierra, con los montos por concepto de obras de reconstrucción, en los créditos que se otorgarán a los beneficiarios del programa

Otras actividades

- convocatoria a la Muestra de Arquitectura Popular "El Rostro de los Barrios"

- convocatoria complementaria it la Muestra ya citada -en coordinación con el Instituto Nacional de Antropologia e Historia- dirigida a los expertos en res tauración, para proyectos de obras a realizarse en 95 inmuebles de valor historico expropiados.

- suscripción de convenios de colaboración técnica con la Universidad Autonoma Metropolitana, el Instituto Politécnico Nacional, el Instituto Nacional de Antro pología e Historia, el Sindicato de Trabajadores de la Universidad Nacional Autó noma de México, el Instituto Mexicano del Seguro Social, el Colegio de Arquitectos de México, la Sociedad de Arquitectos Mexicanos y la Cámara Nacional de la Industria de la Construcción

- reuniones informativas con diversas organizaciones, tales como colegios de profesionales, cámaras industriales, partidos políticos, instituciones financieras y con representantes del Banco Mundial, la ONU y la UNICEF

Construcción e infraestructura del organismo

- instrumentación, habilitación y puesta en operación de 14 jetaturas de zona cubriendo regionalmente los predios expropiados en las delegaciones Cuauhtémoc, Gustavo A. Madero y Venustiano Carranza

- diseño de la estructura organizacional de REvovación; ya tue dictaminada por la SPP

- propuesta del esquema de percepciones: en tabulador de honorarios se encuentra en trámite de autorización

- formulación del programa y del presupuesto generales

- disefio de las reglas de operación del organismo

- estudios y propuesta del programa financiero y reglas para la administración crediticia

- análisis del marco jurídico para determinar el régimen de propiedad más adecuado

- formulación de las normas técnicas

- criterios para la contratación de obra y proyectos

- reuniones periódicas con la junta de gobierno, el comité consultivo y la comision ejecutiva 
teada para tener una existencia de un año, lo cual no garantiza al banco la recuperación del préstamo otorgado. ${ }^{11}$ Otro elemento fundamental para comprender el motivo por el cual se creó otro organismo para llevar a cabo la reconstrucción del centro de la ciudad es que con ello se trataba de abrir nuevos canales de participación popular en la resolución de este problema social; para concretarlo es necesario que los aparatos gubernamentales garantizaran el control político de esta gestión. La elección de un director general con experiencia en materia de organismos de vivienda popular y a la vez dirigente de una de las organizaciones del partido gobernante constituye, en este sentido, una garantía para lograr la capitalización de este esfuerzo gubernamental. No son precisamente los objetivos de racionalidad técnica ni de eficiencia económica que perseguía el elenco gubernamental con anterioridad al terremoto los que llevan a optar por esta política y crear esta institución. De haber sido ésta la intención, otros organismos podían haber asumido la tarea. Lo que está en juego es la posibilidad de que un apoyo real a este sector popular urbano contribuya a incrementar las bases de legitimidad social que persiguen la acción pública y el partido gobernante.

\section{- Los avances del Programa}

Tratando de presentar una visión global del Programa puede decirse que dos son los fines que el mismo persigue:

1) Efectuar trabajos técnicos de reconstrucción de las viviendas. Para ello Renovación Habitacional. Popular está ensayando diferentes formas de organización del trabajo que incluyen: la contratación de empresas constructoras; el reconocimiento de proyectos elaborados por equipos de profesionales que con anterioridad desarrollaban tareas de apoyo en barrios populares (Tepito, La Guerrero) o que se conformaron a partir del terremoto; la posibilidad de que los usuarios aporten trabajo en diferentes tareas

2) Impulsar un proceso de organización vecinal en el que las organizaciones del partido gobernante se vean fortalecidas y en el que se ensaye la participación subordinada de organizaciones autónomas.

Conciliar estos dos objetivos constituye un desafío para quienes dirigen este organismo y para quienes tienen que ejecutar esta política. Aún es imposible predecir el desarrollo que tendrá la acción gubernamental puesto que no se han definido cuestiones fundamentales como son: los sistemas crediticios con los cuales operan los montos de las cuotas en relación con el ingreso familiar, la forma de tenencia definitiva de los predios, la manera y el momento en que se va a transferir la propiedad a los habitantes de las vecindades, el régimen legal de propiedad que va a re-

41 Cfr. Excélsior del 13 de octubre de 1985. 
POLítica DE VIVIENDA

CU.ADRO 23

RENOVACION HABITACIONAL POPULAR

PROYECTO DE PRESUPUESTO 1986

\begin{tabular}{|c|c|}
\hline Subprograma & $\begin{array}{c}\text { Costo (a término de obras) } \\
\text { (millones de pesos) }\end{array}$ \\
\hline Alojamientos provisionales & 4375 \\
\hline Instalación de parques de materiales & 329 \\
\hline Evaluación técnica y proyectos & 1479 \\
\hline Reforzamientos & 300 \\
\hline Reparaciones menores & 8115 \\
\hline Rehabilitación y mejoramiento & 26892 \\
\hline Demolición y reconstrucción & 68035 \\
\hline Construcción de nuevas viviendas & 5600 \\
\hline Supervisión y control de obras & 2213 \\
\hline Adquisición de predios y vecindades & 2000 \\
\hline Subtotal & 119338 \\
\hline Gastos de operación & 5700 \\
\hline TOTAL & 125038 \\
\hline
\end{tabular}

Fente: Informe de Actividades, 15 de enero de 1986.

gir, el mantenimiento de formas habitacionales transitorias, la forma de incorporación institucional de los grupos de asesores y técnicos, el comportamiento de las empresas constructoras y de materiales. De igual forma, como se trata de un proceso que ha ido incorporando una amplia gama de actores sociales que hasta entonces tenían una escasa o nula presencia en este territorio y en procesos de construcción de vivienda popular, el organismo deberá tener una gran flexibilidad en su actuación; deberá controlar el proceso de trabajo pero a la vez deberá lograr acuerdos con todos ellos. En este sentido, debe tenerse presente que no sólo son fuerzas políticas las que se están incorporando a este proceso, sino que organizaciones religiosas (Iglesia católica, metodista, etcétera) instituciones asistencialistas (Cáritas, uniCEF, Ejército de Salvación), instituciones educacionales de nivel superior (UNAM, UAM, IPN), están desplegando una 
intensa labor en estas colonias populares. Todo ello confluye para que efectivamente pueda llevarse a cabo un laboratorio de trabajo colectivo inédito, donde el saldo deberá medirse en términos de la capacidad de las clases populares para ejercer un efectivo control sobre un proceso de gestión urbana tan singular. Si la reconstrucción se lleva a cabo a partir de la acción de los propios protagonistas, contando con el apoyo de las instituciones gubernamentales y de la sociedad civil, podrá inaugurarse un nuevo estilo de relación entre el Estado y las clases populares que contribuya a redefinir las formas clientelísticas que han prevalecido y existen en torno a la cuestión de la vivienda popular. Por el contrario, si fracasa este intento, se reforzarán los mecanismos de asignación de bienes y servicios como uno de los resortes de la gestión gubernamental en que se apoya el partido gobernante para lograr consenso. Por ello, debe impulsarse un proceso en que el Estado sea visto como un organismo público que represente los intereses del conjunto de ciudadanos que pretende beneficiar. El éxito del programa descansará también en la superación del burocratismo que caracteriza a la gestión pública en el sentido de responsabilidad social de los miembros del aparato gubernamental que participan en estos procesos. Evitar que el programa se desvirtúe depende en gran medida de que los canales de participación estén abiertos a todas las organizaciones sociales y que los vecinos ejerzan un efectivo control social del proceso.

Finalmente, debe pensarse que el programa de reconstrucción es mucho más amplio y que abarca otros puntos nodales para reconstituir la vida cotidiana. Quedándonos solamente en la esfera de los bienes de servicios urbanos, la factibilidad del programa depende en gran medida de que la reconstrucción de vivienda en vecindades se articule correctamente con las acciones en materia de: edificación de lotes baldíos, instalación de infraestructura y equipamiento, reparación de otros edificios dañados que constituyen importantes fuentes de empleo para la población, etcétera. En cada uno de estos proyectos están presentes diferentes instituciones del Estado y diferentes agentes sociales, lo cual debe ser considerado para evaluar correctamente la complejidad de la acción que se está llevando a cabo.

\section{Perspectivas de muY corto plazo}

En materia de política habitacional, 1985 debe marcar cambios de orientación y acción. Así como la creación de los fondos habitacionales (INFONAVIT, FovisSSTE) a principios de los años setenta implicó la pues ta en marcha de una política financiera y social diferente a la que vení: desarrollándose hasta entonces, septiembre de 1985 puede ser consideradi) como un momento a partir del cual deben replantearse cuestiones centra. 
les. Entre éstas merecen ser revisadas: el propio diagnóstico de la situación habitacional que prevalece en la ciudad de México y en el país; las formas de relación entre el Estado y los usuarios de la vivienda de interés social, la participación de diferentes actores sociales en la resolución del problema de la vivienda popular (principalmente los organismos financieros internacionales, los promotores de vivienda y las empresas constructoras) y los mecanismos de elaboración y concreción de una política que responda a las necesidades populares.

Alrededor de estas cuestiones deben abrirse espacios de discusión y debate de los que surjan nuevas formas de interpretar viejos problemas $y$, sobre todo, donde se vayan elaborando soluciones inmediatas y factibles para enfrentar problemas de la gravedad que presentan las condiciones habitacionales actuales. Tres hechos sociales deben ser incorporados en el análisis, puesto que enmarcan los efectos atribuibles al terremoto: 1) el contexto de crisis económica, 2) el recambio de grupos técnicos políticos que actúan en los aparatos gubernamentales encargados del problema habitacional y la decisión de disminuir el personal del Estado para hacer frente al recorte presupuestal, 3) las formas de relación social entre organismos y los demás actores sociales involucrados en la cuestión.

\section{a) El contexto de la crisis económica}

En primer término, es importante repensar la política habitacional en el contexto de crisis en que se halla el país. Intentando enfatizar solamente aquellos factores que poseen mayor incidencia en el problema habitacional podemos mencionar: 1) el deterioro real del ingreso de los trabajadores y 2) la escasez de recursos gubernamentales dedicados al gasto social y particularmente a la vivienda. En relación con las condiciones laborales, es sabido que los incrementos salariales no han acompañado los incrementos de los precios de los principales artículos que componen la canasta familiar. La vivienda, bien caro y escaso, particularmente en las áreas urbanas del país, constituye un gasto que suele absorber un elevado porcentaje del ingreso familiar. Sin embargo, en la crisis existen consumos inmediatos que no admiten postergación, como el gasto para la alimentación. La forma como masivamente la población trabajadora ha enfrentado la solución del problema habitacional ha sido la autoconstrucción o autogestión de una vivienda precaria en la periferia de las grandes ciudades, aceptando condiciones de vida deterioradas, inestabilidad en la tenencia de la tierra y acceso deficiente a servicios elementales como agua y drenaje.

El Estado venía prestando a este proceso una atención limitada y puntual a través de organismos gubernamentales, la cual pretendió modifi- 
carse en 1981 con la creación del Fondo de Habitaciones Populares. ${ }^{42}$ Este organismo, con antecedentes como INDECO y la experiencia de algunos organismos que actuaban en el ámbito estatal, intenta poner en marcha una política habitacional de apoyo a la autoconstrucción de viviendas, mejoramiento de servicios y equipamiento y obtención de tierra para construir vivienda popular, otorgando crédito no a individuos $\odot$ familias sino a grupos (cooperativas $u$ otras formas de organización) de no menos de 100 familias cuyo ingreso sea menor a 2.5 veces el salario mínimo, lo cual engloba a más del $70 \%$ de la población del país (Cfr. Ortiz, 1985). Sin embargo, la incidencia de FONHAPO debe ser relativizada en el contexto de la política habitacional. Este organismo aporta un importante porcentaje de las acciones (15.13\% del total de las acciones del Programa de Vivienda para 1985) pero en 1985 sólo recibió el 4.03 por ciento del total de la inversión para el mismo año (cuadros núms. 17 y 18). En contrapartida, la acción pública ha dedicado el grueso de los recursos durante más de una década a la producción de vivienda terminada, ya sea producida por los fondos habitacionales (INFONAviT y Fovissste) o financiada por la Banca y el Programa Financiero de Vivienda.

Estos datos oficiales son un indicador de la orientación que ha tomado la política habitacional desde hace más de una década. Es crucial para el país mejorar las condiciones de habitación de la fuerza de trabajo, pero aún entre los trabajadores que poseen mejores y estables salarios y están organizados sindicalmente sólo un número muy pequeño logra acceder a una vivienda adecuada. Entre las necesidades reales y las posibilidades de que el Estado genere una oferta acorde a las mismas, ofreciendo reales mejoras en las condiciones de vida, existen obstáculos muy difíciles de vencer. Esto es importante enfatizarlo porque justamente un día antes del terremoto, el 18 de septiembre de 1985, se llevó a cabo una reunión de Evaluación del Programa Nacional de Vivienda con la participación de representantes de los organismos de vivienda, la banca, la industria de la construcción y el sector obrero organizado, en la que según las informaciones periodísticas prevaleció la idea de que en el trienio los logros alcanzados permitían suponer que "el problema de la vivienda es resoluble"; idea sustentada en el hecho de que todo lo ejecutado en estos años es mayor a lo realizado en el sexenio anterior (632 894 millones para 327717 viviendas terminadas y un total de 591590 acciones sólo en 1985). El hecho de evaluar el déficit habitacional en 3 millones de viviendas debe ser considerado tan sólo como un dato cuantitativo que permita aproximarnos a la magnitud que presenta el problema habitacional.4s

Sin embargo, una de las enseñanzas del terremoto es que existe un

42 Sobre la participación del Estado en Programa de Autoconstrucción, véase Mier y Terán y Ziccardi (1985).

43 Cfr. Carmen Llorens (1985): como puede confrontarse, esta cifra es diferente en los discursos de altos funcionarios. 
gran deterioro habitacional, precariedad, hacinamiento, insalubridad, condiciones de vida que comparten un elevado número de familias de trabajadores rurales y urbanos. La crisis agrega otro componente: en una situación de escasez de recursos esta precariedad habitacional se incrementará puesto que en las estrategias de sobrevivencia que experimentan las clases populares urbanas los gastos por alojamiento y/o mantenimiento de sus viviendas no son prioritarios. Por otra parte, el sismo puso al descubierto las dificultades económicas y sociales que encierra la acción estatal en la materia. El proceso de reconstrucción con todas las dificultades que deberá sortear debe ser observado con todo cuidado porque en el mismo se ponen en juego un conjunto de relaciones sociales que se estructuran a partir de las necesidades de vivienda y que no son contempladas por lo general en los programas gubernamentales.

Continuar con la idea de que en la crisis se puede poner en marcha el "más ambicioso programa habitacional" y con ello resolver el problema de la vivienda, parece una apreciación bastante lejana de lo que efectivamente se puede realizar para mejorar la situación habitacional. Por ello, 1985 debiera ser un parteaguas en la orientación que desde hace más de una década se imprimió a la política habitacional.

\section{b) El personal del Estado}

En los primeros meses de 1985 se produjeron importantes cambios en el sector de la burocracia encargado de la cuestión habitacional. La renuncia del entonces titular de la SEDUE, licenciado Marcelo Javelly Gerard y su reemplazo por el arquitecto Guillermo Carrillo Arenas marcaba el inicio de un recambio en el elenco gobernante. El sexenio se había iniciado con una reestructuración de la anterior sAHOp que, en materia de vivienda, había significado la creación de una Subsecretaría de Vivienda y la promulgación de la Ley Federal de Vivienda.4 Los fondos habitacionales, en cambio, no presentaron modificaciones institucionales y continuaron actuando en función de los intereses políticos, burocráticos y sindicales que se instalaron en su interior desde su creación. La planeación de SEDUE, que continuaba los lineamientos elaborados en el sexenio anterior y contenidos en el Programa Nacional de Vivienda, no logró nunca alterar la inercia con que actuaban los organismos de vivienda de interés social. Las limitaciones de los más altos niveles de decisión para lograr consolidar un espacio en el interior de la lucha intraburocrática llevó al relevo del Secretario de sEDUE y de sus colaboradores más inmediatos. El nuevo personal pretendió desde un inicio presentar una imagen dife-

44 Véase Ziccardi (1985). El 17 de febrero de 1986 se dio a conocer la renuncia del arquitecto Guillermo Carrillo Arena y el nombramiento del licenciado Víctor Manuel Camacho Solis como nuevo secretario de la sedue. 
rente de la gestión gubernamental en materia de desarrollo urbano y vivienda. En lo fundamental, presentó un objetivo de reordenación administrativa y de recomposición del terreno de las alianzas entre la burocracia del gobierno federal, los organismos financieros, las instituciones de vivienda, las representaciones gremiales de los trabajadores sindicalizados y los empresarios de la industria de la construcción. Tal vez la reunión a la que se hizo mención, en la que se evaluaba el Programa de Vivienda, pretendía consolidar precisamente este inestable equilibrio de los actores sociales que participan en la cuestión de la vivienda de interés social. Así, el problema de la vivienda y la acción gubernamental en torno al mismo, adquiría rápidamente un carácter político, relegándose la imagen tecnocrática que pretendió darse durante la anterior administración. En este contexto se dieron a conocer las medidas de recorte presupuestal que venían a afectar en mayor o menor medida al conjunto de la burocracia estatal.

De la SEDue se despidió a un considerable número de técnicos y profesionales para los cuales no es fácil encontrar opciones ocupacionales alternativas en un contexto de crisis y de desocupación masiva de burócratas. Todo este movimiento interno de personal se daba precisamente en el momento en que la secretaría de gobierno pretendía legitimarse en la estructura de la administración pública demostrando su capacidad de acción pública en cuestiones nacionales tales como la vivienda, el desarrollo urbano y la ecología. Los sismos del 19 y 20 de septiembre sacudieron fuertemente los más ambiciosos proyectos institucionales y personales. La naturaleza, con su saldo de muertes irreparables, evidenció crudamente las limitaciones de agencias, programas, formas de relación entre las instituciones y los usuarios, necesidades y opciones habitacionales.

La política gubernamental en materia de vivienda deberá reorientarse necesariamente. La situación de los damnificados, sus organizaciones sociales, expresan la existencia de problemas que demandan una solución acorde a la complejidad de los mismos. Entre éstos podemos considerar dos de fundamental importancia. En primer término, la emergencia demostró la capacidad de los organismos de vivienda de dar una respuesta relativamente rápida pero limitada. Habiéndose afectado un importante número de viviendas de las capas medias de trabajadores de los servicios gubernamentales y privados, que son sujetos de créditos de los fondos habitacionales o que poseen ingresos suficientes para acceder a los préstamos de la banca, más de la mitad de los damnificados tienen una opción que pueden aceptar o rechazar según responda o no a sus expectativas. Para aproximadamente 40000 familias del centro de la ciudad, la respuesta gubernamental debió alcanzar un mayor grado de compromiso porque de esta población, de inestables y bajos ingresos, sólo un porcentaje menor era acreditado de los fondos y la oferta de estos organismos se ubicaba lejos de su localización actual. Por ello, el gobierno debió res- 
ponder a la emergencia creando un organismo, en principio de vida efimera, que tendrá a su cargo la enorme responsabilidad de hacer que el decreto de expropiación de esas 3911 vecindades se traduzca, en los hechos, en una medida que responda a los intereses de las clases populares del centro de la ciudad, reconstruyendo su vivienda y garantizando su arraigo. Evidentemente el reto para la política habitacional del Estado mexicano en este momento no es demostrar que puede generar instancias institucionales para la solución de graves problemas, sino que efectivamente estas instancias solucionen los problemas. En este sentido, crear un organismo puede contribuir a incorporar nuevamente a un conjunto de técnicos y profesionales desempleados meses atrás o amenazados de estarlo, pero el desafío es visualizar los componentes centrales de la política habitacional: las características del suelo urbano, los destinatarios de la acción, las formas organizativas, el tipo de tenencia, los mecanismos financieros. La posibilidad de continuar operando con criterios y normas ideados en una coyuntura en la que importantes recursos se podían destinar a la producción de vivienda popular, encontró su límite en la aparición de las nuevas e inesperadas demandas de los damnificados.

En segundo lugar, la forma de participación del Estado en la cuestión habitacional, que se tradujo en su contribución a producir, financiar y/o administrar grandes conjuntos habitacionales desde fines de los años cincuenta, ha sido cuestionada por el drama. Lejos de representar el interés colectivo, la construcción de estas viviendas van acumulando un conjunto de problemas sociales, económicos, urbanísticos y políticos que merecen revisarse sin demora.

\section{c) La relación entre los organismos públicos y los actores sociales involucrados}

Éste es un tema que demanda ser analizado en el interior de los procesos globales de democratización de la gestión pública y de la sociedad que diferentes actores vienen sustentando. En este sentido debe señalarse que la gestión de la ciudad, entendida como la forma de provisión y administración de los principales servicios urbanos (no sólo la vivienda), debe ser repensada en función de importantes cambios que se han producido en la realidad social. En algunos casos se han introducido ya modificaciones en la legislación, como es en el caso del artículo constitucional 115 que otorga facultades esenciales a los municipios para la captación de recursos fiscales, tales como el impuesto predial, y para que este nivel gubernamental administre los principales servicios públicos. En el caso del DDF, una gestión marcadamente centralizada ha llevado a que los bienes y servicios de la ciudad sean of recidos por las instancias administrativas. En materia de vivienda, las formas de relación entre las clases po- 
pulares y los organismos públicos participantes en la cuestión han atravesado por diferentes etapas, asumiendo distintos rasgos en cada una de ellas. Las primeras colonias populares formadas a partir de la concesión gubernamental de tierras en los años treinta dieron origen a la instalación de relaciones de tipo clientelístico entre líderes y trabajadores para la obtención de mejoras progresivas que el aparato estatal, el DDF, intentó institucionalizar con la creación de oficinas de gobierno para atender tales cuestiones (tal es el temprano origen de la Oficina de Colonias Populares). Los trabajadores sindicalizados ya desde esas épocas podían acceder a la escasa oferta habitacional controlada por sus dirigentes, cuestión ésta que se mantuvo aún cuando dicha oferta creció sustancialmente con la creación del Programa Financiero de Vivienda en los sesenta y los fondos habitacionales (INFONAvit y FovisSSTE) en la década siguiente. El azar es el único mecanismo que puede reemplazar la existencia de relaciones personales en la asignación de viviendas a los derechohabientes. En este sentido, la creación de SAHOP en el sexenio pasado y de SEDUE en éste no significó modificación alguna en las formas de operación que presentan los organismos. Su función de coordinar las acciones de vivienda como cabeza del sector de asentamientos humanos no se concretó en los hechos y sus lineamientos respecto al destino de la acción gubernamental no trascendieron el nivel discursivo. Durante 1985 esta institución federal llevó a cabo un intento de búsqueda de consenso entre las organizaciones del movimiento obrero organizado (Cт у CTM). Sin embargo, ello no se tradujo en modificaciones del actuar institucional. Tampoco se tradujo en la satisfacción de las demandas de estas agrupaciones gremiales (incremento del aporte patronal al $10 \%$, estímulos a las empresas sociales productoras de insumo, construcción de vivienda en renta, apoyo a la autoconstrucción en el caso del cr, etcétera)..$^{45}$

Pero las clases populares urbanas poseen otras formas de representación ciudadana que son las organizaciones vecinales. Estas formas de asociación, que presentan los residentes de conjuntos habitacionales o los barrios con larga tradición de lucha como Tepito o la Gucrrero, o de las nuevas colonias populares (movimiento urbano popular) son actores sociales cuyas demandas deben ser incorporadas en la ejecución de una política de vivienda popular más amplia que la reconstrucción de lo dañado por el terremoto. La posibilidad de que los escasos recursos sean asignados a un número mayor de beneficiarios y que con ello se logre una calidad de vida superior, descansa en el hecho de que estos sectores sociales desarrollen sus propias formas organizativas. La calidad de ciudadano debe contruirse en el reconocimiento de diferentes formas de participación social que contribuyan a tornar más eficiente y justa la gestión gubernamental. En este sentido debe tenerse en cuenta que los sismos permitieron la incorporación de nuevos actores sociales que la política habitacional deberá con- 
templar: 1) La presencia de organismos de carácter religioso y asistencialista que están apoyando el proceso de reconstrucción con recursos económicos. Este tipo de instituciones ha desarrollado una amplia experiencia en el contexto latinoamericano en países como Brasil, Perú y Colombia, participando en programas de vivienda popular y gestando formas organizativas de tipo vecinal, recreativo y/o religioso que lograron imprimir a estos procesos sociales características particulares. ${ }^{46}$ 2) El hecho de que las universidades del país han venido desarrollando, en el terreno de la investigación y la docencia, un conjunto de experiencias muy importantes en relación con la vivienda popular. De las instituciones educacionales de nivel superior han salido análisis críticos en los que el compromiso académico ha sido exclusivamente el de defender los intereses de la comunidad. Las escuelas de arquitectura, de economía, de ciencias políticas y sociales han aportado elementos clave para la interpretación de las necesidades de vivienda, de las modalidades de las acciones públicas, de las formas de organización que han desarrollado los colonos, de sus demandas y luchas, de las limitaciones que presentan los cuerpos legales e institucionales para hacer frente al problema habitacional. Sin embargo, también en este caso sólo los sismos abrieron las posibilidades de que la producción académica y el trabajo de los universitarios con la comunidad encontrara un pequeño espacio de validación, el cual deberá consolidarse en algunos aparatos del Estado.

46 Existe una abundante bibliografia sobre esta temática. Entre los trabajos más importantes véase Alfredo Rodriguez (1972) y Anthony y Elizabeth Leeds (1978). 


\section{BIBLIOGRAFÍA}

Astorga, Luis: (1985), Naturaleza sociedad y política, Instituto de Investigaciones Sociales de la UNAM (mimeo).

Azuela, Antonio, Miguel Cancino y Ma. Soledad Cruz: (1984), "Ilegalidad y procesos sociales en cuatro colonias populares de la Ciudad de México", en Revista A, uAM Azcopotzalco, vol. v, núm. 11, eneroabril, México, p. 113-148.

Berra Stoppa, Erika: (1980), El movimiento inquilinario en la ciudad de México 1916-1926, México, Centro de Estudios Históricos, El Colegio de México.

Camarena, Margarita: (1986), "Efectos de los sismos sobre el transporte", en Revista Facultad de Ciencias Políticas y Sociales, México, unam (en prensa).

Calpulli: (1985), La expropiación a beneficio de los damnificados, Boletín del centro de apoyo a movimientos sociales urbanos, agostooctubre, núm. 3, p. 6.

Carrillo Arena, Guillermo: (1985), Palabras pronunciadas en la instalación de la Coordinación de Vivienda, México, Presidencia de la República, octubre, p. 19 a 23.

Castillo Berthier, Héctor F.: (1983), "El mercado de la Merced antes del cambio", en Revista Mexicana de Sociología, México, unam, julioseptiembre, vol. xLv, núm. 3, p. 857-875.

Comisión Metropolitana de Emergencia: (1985), "Informe", Excélsior, México, 19 de septiembre-19 de octubre, México.

Gomisión Nacional de Reconstrucción: (1985), México está én pie. México saldrá adelante porque está unido, México, Presidencia de la República, octubre.

Comisión Nacional de Reconstrucción. Comité de Descentralización: (1986), "Acuerdos básicos sobre la descentralización", en Excélsior, México, 28 de enero.

Connolly, Priscilla: (1985), "El inquilino antes y después del sismo", en Revista El Cotidiano, UAM Azcapotzalco, México, noviembre-diciembre, año II, núm. 8, p. 39-44.

COPEVI: (1974), "Tepito: ¿ Regeneración o desintegración de un barrio?, en Revista dinámica habitacional, Centro Operacional de Vivienda, A.C., época III, núm. 2, México.

COPEVI: (1977), "Inquilinato: Mitos y realidades", en Revista dinámica habitacional, Centro Operacional de Vivienda, A.C., época III, núm. 12, México.

Coulomb, René: (1985), "La vivienda de alquiler en las áreas de reciente urbanización", en Revista A, UAM Azcapotzalco, mayo-agosto, vol. vI, núm. 16, México, p. 43 a la 69. 
Departamento del Distrito Federal: (1984), Programa de Reordenación urbana y protección ecológica del Distrito Federal, México.

Departamento del Distrito Federal: (1982), Dirección de Planificación Plan Parcial de Desarrollo Urbano, Delegación Cuauhtémoc, México. Departamento del Distrito Federal: (1982), Dirección General de Planificación, Plan Parcial de Desarrollo Urbano, Delegación Venustiano Carranza, México.

Diario Oficial de la Federación: (1985), Decreto por el que se expropian por causa de utilidad pública, los inmuebles de propiedad privada que se señalan, 21 de octubre, México, $198 \mathrm{pp}$.

Diario Oficial de la Federación: (1985), Acuerdo por el que se crea la Comisión de Reconstrucción del Distrito Federal, 11 de octubre, México.

Fraga, Gabino: (1985), "Intervención ante los representantes del Congreso del Trabajo", en Excélsior, 21 de mayo, México.

Garza, Gustaco (coord.): (1986), Atlas de la Ciudad de México (en elaboración), México.

Gosselin Maurel, Carlos: (1985), Palabras pronunciadas en la instalación de la Coordinación de Vivienda, Presidencia de la República, México, octubre, p. 45-47.

Grajales V., Carolina y Felipe Laro Rosano: (1983), "Las decisiones políticas en transporte: el caso del aeropuerto de la Cd. de México", en Revista Mexicana de Sociología, UNAM, julio-septiembre, vol. Xuv, núm. 3, México, p. 915-932.

Hernández Vicente, Martín: (1977), "La vivienda del porfiriato en algunas colonias de la ciudad de México, $1^{\text {a }}$ parte", en Revista Arquitectura Autogobierno 8, unam, septiembre-diciembre, México, p. 17 a 23.

Hernández Vicente, Martín: (1978), "La vivienda del porfiriato en algunas colonias de la ciudad de México", en Revista Arquitectura Autogobierno, UnaM, enero-junio, núm. 9, México, p. 25-35.

IISUNAM: (1985), Encuesta a damnificados en albergues y campamentos, septiembre, México.

Krauze, Enrique: (1985), "Revelación entre las ruinas", en Vuelta, año $\mathrm{rx}$, núm. 108, México, noviembre, p. 11 a 14.

Leeds, Anthony y Elizabeth: (1978), La sociología del Brasil urbano, Río de Janeiro, Zahar.

Liberman, Leopoldo: (1985), Palabras pronunciadas en la instalación de la Coordinación de Vivienda, México, Presidencia de la República, octubre, p. 29 a 31.

Llorens F., Carmen: (1985), "Hablan los colonos", en El Cotidiano, vam Azcapotzalco, noviembre-diciembre, año II, núm. 8, México.

Massolo, Alejandra: (1986), ¿Que el gobierno entienda, lo primero es la vivienda!, en este número. 
Llorens F., Carmen: (1985), "El programa nacional de vivienda: Un balance antes del sismo", en El Cotidiano, UAM Azcapotzalco, noviembre-diciembre, año II, núm. 8, México, p. 57-61.

Mier y Terán, Arturo y Alicia Ziccardi: (1985), Autoconstrucción y acción pública, en Vivienda, vol. 10, núm. 1, enero-junio, INFONAvrT, México, p. 48-67.

Monje, Raúl: (1985), "La expropiación de predios de regreso, para corregirla", en Proceso, 21 de octubre, núm. 468, México, p. 18 a 27.

Monsiváis, Carlos: (1985), "Organizaciones populares y resistencia a su acción", en Proceso, 11 de noviembre, núm. 471, México, p. 15 a 17.

Mora, Felipe: (1985), Sismo y crisis: elementos para la reconstrucción analítica de la coyuntura en la óptica del poder (mimeo).

Moreno Toscano, Alejandra (coord.): (1978), Ciudad de México, ensayo de construcción de una historia, México, SEP-INAH.

Morales, María Dolores: (1978), "La expansión de la ciudad de México en el siglo xix: el caso de los fraccionamientos", en Moreno Toscano A. (coordinadora), Ciudad de México. Ensayo de construcción de una historia, México, SEP-INAH, p. 189 a 200.

Ortega, Silvia y otros: (1985), "Tepito: entre la tradición y el suspiro de la reconstrucción", en El Cotidiano, uAm Azcapotzalco, noviembrediciembre, año II, núm. 8, México, p. 53-56.

Ortiz Flores, Enrique: (1985), El financiamiento público de la vivienda, junio, ronhapo, México (mimeo).

Paz, Octavio: (1985), "Escombros y semillas", en Vuelta, noviembre, año rx, núm. 108, México, p. 8 a 10.

Perló, Manuel: (1981), "Estado, vivienda y estructura urbana en el cardenismo", en Cuadernos de Investigación Social, núm. 3, vol. v, México, IISUNAM.

Renovación Habitacional Popular. SEDUE-DDF: (1985), ¿Qué es renovación?, México, SEDUE-DDF.

Robles, Manuel: (1985), "Sin solución para los afectados se intenta ya cerrar albergues", en Proceso, 4 de noviembre, núm. 470, México, p. 20 a 27.

Rodríguez, Alfredo, Gustavo Riofrío y Eileen Welsh: (1972), "De invasores a invadidos", en Revista EURE, vol. II, núm. 4, marzo, Santiago.

Rosenblueth, Emilio: (1986), Entrevista realizada por Enrique Krauze: "Mudar la Ciudad de México", en Vuelta 110, año Ix, enero, México, p. 39-43.

Saldívar V., Américo: (1985), Liberalismo y proyecto nacional en el siglo XIX (mimeo), México, Departamento de la Facultad de Economía de la UnAM.

sedues (1986), "Informe que presenta la sfdue a la $H$. Comisión Especial Pluripartidista del H. Congreso de la Unión acerca de la situación 
que guarda la atención a los damnificados de vivienda en la ciudad de México como producto de los sismos del 19 y 20 de septiembre de 1985" (mimeo), México, enero.

SEDUE: Subsecretaría de vivienda. Sistema de Información de Vivienda. Seguimiento y control de atención a damnificados, México, 22 de enero de 1986.

Servicios Informativos Procesados: (1985), Cronología de los acontecimientos, declaraciones y editoriales en torno al sismo del 1 al 15 de octubre de 1985 aparecidos en los principales diarios, anexo especial del número 16 de Cronologías e Indicadores Internacionales y $\mathrm{Na}$ cionales, octubre, México.

Suárez Pareyón, Alejandro: (1977), "La colonia Guerrero: un caso de deterioro urbano en la ciudad de México, $2^{\text {a }}$ parte", en Arquitectura Autogobierno 8, unam, septiembre-diciembre, México, p. 24 a 30.

Suárez Pereyón, Alejandro: (1978), "La colonia Guerrero: Un caso de deterioro urbano en la Cd. de México, $3^{\text {a }}$ parte", en Arquitectura Autogobierno, unam, México, enero-junio, núm. 9, p. 36-44.

Tamez, Enrique: (1985), "El sismo, antecedentes y consecuencias", en El Cotidiano, uAm Azcapotzalco, México, noviembre-diciembre, año II, núm. 8, p. 5-8.

Vidrio C., Manuel: (1978), "Sistemas de transporte y expansión urbana: los tranvías", en A. Moreno Toscano (coordinadora). Ciudad de México. Ensayo de construcción de una historia, SEP-iNAH, México, p. 201 a 216.

Ziccardi, Alicia: (1982), "La sociedad cooperativa Plutarco Elías Calles, S.C.L., colonizadora y urbanizadora de los terrenos de la colonia ExHipódromo Peralvillo", en Revista Habitación, año 2, núm. 5, eneromarzo, México, p. 31 a 38.

Ziccardi, Alicia (org.): (1982), Boletín del Archivo Gencral de la Nación, núm. 19, tercera serie, tomo vi, núm. 2 (19), abril-junio, México

Ziccardi, Alicia: (1985), "Problemas urbanos: proyectos y alternativas ante la crisis", en González Casancva, P. y Aguilar C. (coord.), Mexico ante la crisis, México, Siglo xxi, p. 52 a 86.

Ziccardi, Alicia y Carlos Fidel: (1986), "De cal y canto, apuntes sobre la industria de la construcción", en Revista Mexicana de Ciencias Políticas y Sociales, núm. 123, p. 21-37. 